Archaeological Research in Asia 18 (2019) 1-16

https://doi.org/10.1016/j.ara.2019.01.002

\title{
Discovery of an outstanding Hoabinhian site from the Late Pleistocene at Doi Pha Kan (Lampang province, northern Thailand).
}

\section{Valéry Zeitoun}

UMR 7207 CNRS-MNHN-Université Paris VI, Sorbonne Université, Centre de Recherche de Paléontologie Paris, Université Pierre et Marie Curie, T. 46-56, $5^{\text {ème }}$ étage, case 104, 4, place Jussieu, 75252 Paris Cedex 05, France.

\section{Prasit Auetrakulvit}

Department of Archaeology, Faculty of Archaeology, Silpakorn University, Na Phra road, 10220 Bangkok, Thailand.

\section{Antoine Zazzo}

Archéozoologie, Archéobotanique : Sociétés, Pratiques et Environnements (AASPE, UMR 7209), Sorbonne Université, Muséum national d'Histoire naturelle, CNRS, CP55 ou 56, 55 rue Buffon, F75005 Paris, France.

\section{Alain Pierret}

IRD-iEES-Paris, Department of Agricultural Land Management (DALaM), P.O. Box 4199, Ban Nongviengkham, Xaythany District, Vientiane, Lao PDR.

\section{Stéphane Frère}

INRAP-UMR7209, Archéozoologie, Archéobotanique: Sociétés, Pratiques et Environnements, CRAVO, 36 avenue Paul Vaillant Couturier 93120 La Courneuve, France.

\section{Hubert Forestier}

UMR 7194 CNRS-MNHN-UPVD, Institut de Paléontologie Humaine, 1 rue René-Panhard, 75013 Paris, France.

\begin{abstract}
In Mainland Southeast Asia the Hoabinhian culture corresponds to the legacy of using massive tools made on cobbles, a techno-complex that persisted in a tropical environment for about 30,000 years. During this period, human burial practices also appear to be uniform and limited to burials in "flexed" position. However, stasis in cultural patterns is unlikely over such a long time period and large geographic area, and although new data is emerging on nuances in lithic technologies, the limited number of fully documented burials prevents debate on this issue. In a regional review of Hoabinhian burials we discuss the limitations of using the broad term 'flexed' burials, which can conceal important differences/similarities among cases. We use an archaeo-thanatological approach to describe in detail three burials at Doi Pha Kan site, Lampang province, northern Thailand. Differences are observed in the "flexed" positions of the bodies, the anatomical characteristics of the individuals, and the nature of the offerings. General similarities in burial practices among sites in south China and north Vietnam are now documented in northern Thailand at Doi Pha Kan. We promote the archaeo-thanatological approach to generate relevant descriptions of burials, allowing similarities and/or differences in burial practices over time and within/between regions to be accurately assessed. This approach is essential to establish relevant cultural frameworks that can, in the future, be compared with morphological and genetic data to describe population movements and/or cultural indigenous influences on funerary practices in Mainland Southeast Asia.
\end{abstract}


Keywords: Field anthropology; dating; Southeast Asia; Hoabinhian

\section{Introduction}

According to their bio-anthropological study Matsumura et al. (2015) concluded that: "Hoabinhian/Mesolithic populations are key to understanding the peopling of Southeast Asia." Although the striking similarities between the Hoabinhian culture in Southeast Asia and the Late Palaeolithic and Early Neolithic cultures of South China cannot be overlooked, the lack of archaeological investigations in Mainland Southeast Asia, due to more than half a century of regional political instability, has hampered archaeologists demonstrating links between these ancient cultures. Regional archaeologists acknowledge that data sets in Mainland Southeast Asia are biased due to limited sample sizes and uneven geographic coverage of the finds (White, 2011). Concerning the regional sites Higham (2013, p.26) notes that "We could thus think of characterizing the inland Hoabinhian as being subjected to the tyranny of the rock shelter, and the results are almost certainly biased“. In addition, funerary practices are usually described from large Neolithic sites rather than from the rare isolated Hoabinhian burial sites.

In Mainland Southeast Asia the Hoabinhian techno-complex corresponds to the legacy of using massive tools made on cobbles for about 30,000 years. During this long period, funerary practices appear to be uniform and limited to "flexed" burials. Indeed, as stated by Bellwood (1993), Higham (2002), and Rispoli (2007), the only notable changes observed at the end of this period are related to the start of the Neolithic. These changes originated from China and included a sedentary way of life, the start of agriculture, the final abandonment of the chipping/flaking stone industry, and an increase in burials in the extended position. Although these phenomena are well-documented, our knowledge of the diversity of funerary practices in the Hoabinhian period is incomplete. Firstly, published reports lack of information on position, sex, or age at the time of death. Descriptive terminology is imprecise and a lack of illustrations prevents a review of old data, although in recent decades there has been an increase in the archaeo-thanatological approach in Southeast Asia (Pautreau et al., 1998, 2001; Willis and Tayles, 2009; Harris and Tayles, 2012; Zeitoun et al., 2013). Secondly, descriptions of Hoabinhian burials are rare, and considering the existing record of funerary sites in Thailand, Laos, Vietnam, south China and Peninsular Malaysia, there does not appear to be a single inhumation position. This brings us back to the possibility of having various distinct cultures or populations in Southeast Asia during this period.

In this paper, we first give a regional review of Hoabinhian burials (Fig. 1). We demonstrate that imprecise data on the position of buried bodies, and the chronological uncertainty and taphonomic confusion related to inappropriate excavation practices creates inaccurate biocultural backgrounds which should not be compared to new anthropological or genomic data to describe population movements and/or cultural indigenous influences. Second, we describe three graves at the Doi Pha Kan site (N18 26.95' E 99 ${ }^{\circ} 46.62^{\prime}$ ) in Lampang province, northern Thailand (Fig. 2) using an archaeothanatological approach that identifies cultural diversity in burial practices during the Hoabinhian. This approach generates relevant descriptions of burials, allowing similarities and/or differences in burial practices over time and within/between regions to be accurately assessed.

\section{A review of Hoabinhian burials}

In the absence of standardized field anthropological protocols, it is likely that researchers will make false assumptions of similarity between contemporary burials. It also prevents the listing of characters in a summary table to compare different graves. Here we review the descriptions of 
Hoabinhian burials in regional literature, to avoid oversimplification due to the term "flexed" burial. In addition to the review's summary table (Table 1), it is necessary to state the initial descriptions of the uncertain ages attributed to the graves and the position of the bodies, since the iconography is not always available in the source texts.

The Hoabinhian techno-complex originated in south China (Ji et al., 2016). An overview of funerary data from this geographical area shows that the term "flexed" covers different burial configurations. In south China in the central Guangxi province, Liyuzui for period I (9000-8000 BP) has yielded several sites characterized by burials with flexed upper and lower limbs ("crouched position"), chipped pebble tools (choppers, points and scrapers) associated with polished stone axes and perforated tools, as well as innovations such as clam-shell reaping knives with one or two dorsal perforations (Rispoli, 2007). Period IV (12,000 - 8000 BP) burials in the Zengpiyan cave (northern part of Guangxi province) include individuals covered with big sealing blocks, lying on their backs with flexed upper and lower limbs (Rispoli, 2007). Isolated skeletons and individuals lying on their sides with fully flexed limbs were also reported (Rispoli, 2007).

Burials from the "Hoabinhian period" in north Thailand include the very incomplete case at Tham Lod rock-shelter; an adult lying on the back with extended limbs, with a hammer stone lying on top of its lower limbs. The associated sediment beneath the skeleton was radiocarbon dated to 12,100 \pm 60 BP (Shoocongdej, 2006; Khaokhiew pers. comm.). Beneath this burial, an individual buried on its left side in a flexed position was covered by a ring of five large cobbles; the matrix material was radiocarbon dated to $13,640 \pm 80 \mathrm{BP}$. Both burials were in a layer that contained artefacts belonging to the Hoabinhian techno-complex. At Ban Rai rock-shelter, in the vicinity of Tham Lod, the single grave of an adult individual buried on its back, the right arm extended with the lower limbs flexed, the feet raised to the level of the pelvis and the neck flexed forward was discovered in archaeological layers characterized by an abundance of Hoabinhian stone tools and numerous faunal remains (Sidisunthorn et al., 2006). The body was buried directly in the soil within a circular pit devoid of any ornaments or grave offerings. The grave sediment was radiocarbon dated to 9,720 $\pm 50 \mathrm{BP}$ (Pureepatpong, 2006).

At Ban Tha Si, in Lampang province, a grave was uncovered in the vicinity of a rock-shelter with a painted wall (Zeitoun et al., 2013). The individual was lying on its right side. The head was missing, but the upper limbs were flexed with the hands close to the initial position of the chin. The lower limbs were also in a flexed position. The individual had been buried directly in the soil in an unsealed grave. According to the field anthropological study, the sediment had rapidly replaced the volume corresponding to the body flesh, and the grave was probably not much longer or wider than the body itself. The archaeological remains around the burial were dated from 11,390 \pm 36 to 6,673 \pm 25 BP, but the skeleton was dated to $7047 \pm 53$ BP (Zeitoun et al., 2012).

In Kanchanaburi province, in cave II at Sai-Yok, a burial was found in an archaeological sequence which included Neolithic artefacts and Hoabinhian stone tools (Van Heekeren, 1961). The individual was lying on its back on a bed of boulders in the Hoabinhian layer. The soil above the head and part of the body was stained with red ochre. A large mammal bone was resting on the individual's chest and many mollusc shells were present. A heavy quartzite stone slab was placed on the upper part of the body. The face was turned to the right, knees updrawn, and according to Jacob (1969), "the knees were almost vertical with the feet resting flat on the ground. The left arm was flexed across the body, while the right hand was located under the chin". It has been suggested that the upper and lower layers at Sai-Yok cave date back to 4,000 BP and between 10,000 to $8000 \mathrm{BP}$, respectively (op.cit.).

In south Thailand, eight adult graves in Hoabinhian deposits were uncovered at Moh Khiew rock-shelter. Radiocarbon dates of the Hoabinhian level 3 ranged from 11,020 \pm 150 to $8420 \pm 90 \mathrm{BP}$; a single piece of charcoal from a grave was dated to 25,800 $\pm 600 \mathrm{BP}$, while the dates of the two upper levels spanned from $7060 \pm 100$ to $4250 \pm 150 \mathrm{BP}$ (Pookajorn, 2001). The re-examination of the dating 
(Auetrakulvit et al., 2012) determined that the majority of the burials were concentrated in an overlying level dated between 11,220 \pm 510 and $9470 \pm 420 \mathrm{BP}$. Additional uncovered burials were found in level 3, as those excavated by Pookajorn (1990, 1994, 2001). The new series (Auetrakulvit et al., 2012) includes the incomplete skeleton of an adult lying on its back, a poorly preserved individual lying on its back with extended limbs, and an incomplete individual buried in a flexed position on its left side. According to a taphonomical study and information provided by Pookajorn (2001), some "extended" burials discovered during the initial excavation may date back to around 10,600 BP, i.e. the average age of the layer in which it is embedded, while other "extended" and "flexed" burials are likely to be younger than the top of this level (e.g. around 7000 BP) (Zeitoun et al., 2013). Finally, according to the most recent excavation, it is likely that $4250 \pm 150 \mathrm{BP}$ represents the "minimum" age of the former burials. Nevertheless, as the original depth of the burials is inherently variable and there are no reliable means to assess it, it is impossible to determine the precise chronology of the different graves at Moh Khiew (i.e. lying on the side with flexed limbs, lying on the back with flexed limbs and lying on the back with extended limbs).

In central Laos near the Pha Phen rock-shelter in Bolikhamsay province, a single skeleton was found lying on its right side with elbow joints partly flexed so that the forearms were lying across the abdomen (Tayles et al., 2015). The individual's lower limbs were partly flexed at the hip joints and fully flexed at the knee joints. The individual was about $175 \mathrm{~cm}$ tall and was directly dated to $6910 \pm$ $40 \mathrm{BP}$.

In north Vietnam, in Hoa Binh province, Viet (2015) reported two cases of Hoabinhian burials. At Du Sang rock-shelter an individual was buried under blocks and in association with Hoabinhian remains. According to the authors' illustration, the body was buried lying on its back with flexed lower limbs. The forward tilt of the head, the outward rotation of the coxal bones, and the slight outward rotation of the upper limbs in extension alongside the body suggest that non-durable covering had been placed on the individual. Nearby, at Xom Trai (op. cit.), a burial was found in a Hoabinhian layer and was dated to $17,100 \pm 545 \mathrm{BP}$ by a shell sample. The upper part of the body was destroyed but the hip and knee joints were flexed. The individual's height is estimated at $168 \mathrm{~cm}$. At Hang Cho, in Luong Son district, the burial of an individual lying on its back with flexed limbs and raised knees was directly dated to $9259 \pm 206$ BP (Matsumura et al., 2008). The grave appears to have been dug at a depth of 92 $\mathrm{cm}$ through archaeological layers rich in faunal remains and Hoabinhian lithic artefacts.

At Con Moong Cave in the Thanh Hoa province, on the right bank of the Red River, a grave was found in cultural layer II, while three other graves where found deeper in cultural layer I. Ochre and mollusc shells were found near the human remains. Shells from cultural layer II were dated to $11,090 \pm 185 \mathrm{BP}$, while upper cultural layer III was dated to $9905 \pm 150 \mathrm{BP}$ and contained edge ground axes, (Thong, 1980). Ha (1980) reported additional dates for shells in cultural layer I, i.e. 11,755 \pm 75 $\mathrm{BP}$ and $11,840 \pm 75 \mathrm{BP}$, and provided information about the position of one of the burials intruding into the cultural layer I, with the body lying on its back with flexed lower limbs. In the same province Mai Da Nuoc and Mai Da Dieu yielded skeletons that date back to the beginning of the Hoabinhian culture according to Cuong (1986). At Mai Da Dieu, the burials are confined to an upper archaeological layer which contains Hoabinhian stone tools. Arrangements of small limestone pebbles surrounded by larger stones at the base of the burials were reported, but no details were given on the position of the bodies. At Mai Da Nuoc, an individual lying on its back with extended limbs (84/MDN.M1) was found in association with lithic artefacts. Gravel and large stones were found at the base of the grave and six half-ground seashells were identified just below the individual's neck.

At Bàu Du, in Quàng Nam Dà Nàng province, Ha (1995) reported the presence of flexed burials dug in deposits rich in Hoabinhian artefacts, including an unfinished perforated stone. Radiocarbon dates obtained from charcoal collected at this site yielded a very early chronological range for the 
Hoabinhian, from $4510 \pm 50$ to $5030 \pm 60 \mathrm{BP}$. However, it is not mentioned whether these dates relate to the burials or deposits. In the same province, at the Con Co Ngua site, Da But graves were generally only earthen pits with no sign of any covering material. However, five single burials were associated with stone markers on top of or beside the graves. Red mineral powder was spread over at least one burial cluster and ochre was also found in two other separate graves (op. cit.). In general, as observed by Tayles et al. (2015) referring to Oxenham $(2000,2006)$, the Con Co Ngua burials yielded bodies arranged in a similar way to those at Ban Tha Si, but with the body placed upright with the limbs fully flexed. In general, Con Co Ngua skeletons also correspond to tall individuals. The Da But culture takes its name from the work of Patte (1932) and is partly characterized by edge polished stone tools (Viet, 2005). Da But sites are generally characterized by large shell-midden deposits, edge ground pebble axes, and burials with individuals frequently found in tightly flexed but upright positions, with limited grave offerings and no pottery (Oxenham et al., 2005). Da But culture is considered to be one of the several emergent Neolithic cultures that developed out of the Hoabinhian around 6500 to $6000 \mathrm{BP}$, and was based on a coastal/marine economy (Oxenham, 2006).

In north Malaysia at Gua Gunung Runtuh in the Lenggong district of the Malaysian state of Perak, an individual was found lying on its back, the upper and lower limbs flexed, with the left hand resting on the abdomen (Jacob and Soepriyo, 1994). The grave included freshwater gastropod shells radiocarbon dated to $9460 \pm 90$ to $10,120 \pm 110 \mathrm{BP}$. The oldest date of $13,600 \pm 120 \mathrm{BP}$ was obtained from shells found at the bottom of the burial (Zuraina, 1994). Offerings comprised of faunal remains, a flat limestone slab sprinkled with red powder, a quartz hammer stone and one oval unifacial pebble tool placed next to the head of the individual. There were also miscellaneous tools around the body that was covered with shells. The presence of similar artefacts in so-called pre-ceramic levels in other caves of the Perak state, assuming that this can be considered as an indicator of contemporaneity, seems to point to similar practices at Gua Kerbau about $40 \mathrm{~km}$ away from Gua Gunung Runtuh where one skeleton was buried with knees drawn up to the chest (Zuraina, 1994). In the lowest level of Go B'ait a skeleton was found buried in "flexed" position (Callenfels, 1939), and at the shell- middens of Gua Kepah Jacob (1967) noted that human remains were associated with grinding stones, sumatraliths, stone axes, and also potteries, beads, and animal remains belonging to the Hoabinhian. At Gua Teluk Kalawar near Lenggong, one individual buried on its back, the right arm in a hyperflexed position brought back to the thorax and the left arm flexed on the left side of the trunk, the lower limbs crossed and flexed to a bent position resting on the right side, and the feet raised below the level of the pelvis was buried with animal remains surrounding its skull. The body was covered in riverine shells, with haematite powder sprinkled on and around the body (Zuraina et al., 2005). The burial intersect layers containing shells and Hoabinhian tools. A date obtained from charcoal indicated an age of 10,245 $\pm 80 \mathrm{BP}$ about $90 \mathrm{~cm}$ below the burial, while a shell associated to the body was radiocarbon dated to 8,400 $\pm 40 \mathrm{BP}$ (op. cit.).

Burials of the rock-shelter of Gua Cha near the Nenggiri River in Peninsular Malaysia, contained individuals with lower limbs crossed and flexed, the feet raised below the level of the pelvis in the Hoabinhian layers. This Hoabinhian occupation dates back to $10,000 \mathrm{BP}$, but apart from a charcoal sample from the middle of the deposits, with an age of $6300 \pm 170 \mathrm{BP}$, radiocarbon dating of this site appears equivocal (Bulbeck, 2000).

This regional review of Hoabinhian burials shows that few cases are described in sufficient detail for valid comparisons or conclusions. In addition, some graves cannot be assigned to the Hoabinhian; it is likely that they were Neolithic burials dug in Hoabinhian archaeological levels, for example at Sai Yok. This observation echoes our former conclusions (Zeitoun et al., 2012, 2013) that agree with those of White (2011): detailed data analyses following a modern archaeological approach is needed to establish a relevant chronocultural framework. Such an approach is also needed for bioarchaeological data (Oxenham, 2006). 


\section{Materials and methods}

At Doi Pha Kan several red-ochre painted figures are present: hands, carnivores, proboscideans, bovids, a gallinacae associated with anthropomorphic forms, and geometric figures (Surinlert et al., 2018). A similar association between rock-shelter paintings and burials has also been observed at Phratu Pha and Ban Tha Si. Following an archeo-thanatological approach, we describe in detail three exceptional burials discovered at Doi Pha Kan. Due to their characteristics, i.e. the nature of the uncovered offerings, the period they correspond to, and the anthropological features of the remains they contain, they could be related to a population that is distinct from the traditional regional Hoabinhian cultural background. This has been recently proposed based on the geographical distribution of perforated stones in Southeast Asia (Imdirakphol et al., 2017).

Doi Pha Kan deposits are dusty, loamy sediments accumulated over a decadeth of at least $2 \mathrm{~m}$. Due to the loose nature of the deposits the site was excavated very carefully to avoid disturbing the sediments and embedded archaeological remains; small successive trenches less than $90 \mathrm{~cm}$ deep were excavated (Fig. 3). Another remarkable taphonomical property of the site is that no distinctive layer could be identified during the excavation. All artefacts exceeding a length of $1 \mathrm{~cm}$ in at least one dimension were recorded in three dimensions. Smaller objects were collected by sieving out $5 \mathrm{~cm}$ thick sediment layers taken from $1 \mathrm{~m}^{2}$ plots. The density of all the remains and artefacts was used as a criterion to characterize archaeological layers.

Initially, the excavation work focused on the burials within deposits containing both stone artefacts and faunal remains, logically older than the graves themselves. With 2,144 lithic artefacts and 31,699 faunal remains, the mean density of the material was high, at 3,109 objects per $\mathrm{m}^{3}$. Due to the intersecting position of the graves, the refilling of the graves, and the archaeologically rich sediment, it is not yet possible to provide a valid date for the lithic artefacts nor of the faunal remains of the nearby deposits. Therefore, a short description of this rich lithic and archaeo-zoological material is detailed here.

We followed a field anthropological or archaeo-thanatological approach: the meticulous observation of the anatomical orientations of bones in a grave, so as to interpret how their original arrangement changed as the body decomposed. The aim is to determine the original burial context (Duday et al., 1990) and uncover new burial modalities (Duday and Guillon, 2006; Duday et al., 1990; Willis and Tayles, 2009; Zeitoun et al., 2013). These modalities are often undocumented, despite Duday et al.'s (1990) assessment that they represent a fundamental component of mortuary practices.

This approach is rather rare in Southeast Asian archaeological research and it is therefore difficult to conduct valid comparisons between detailed studies in this region. In addition, reappraisal of earlier publications and/or data sets is a prerequisite for relevant comparisons with more recent archaeo-thanatological studies (see Auetrakulvit et al., 2012; Bulbeck n.d.; Harris and Tayles, 2012; Lloyd-Smith, 2012; Tayles et al., 2015; Hiep and Huffer, 2015).

Three adult and four child (10 months old) burials were uncovered at Doi Pha Kan. Bone remains were very fragile and only limited biological data could be collected directly on-site. Sexing was determined using the DSP method (Murail et al., 2005) and height was calculated from two regional anthropological tables (Mahakkanukrauh et al., 2011; Pureepatpong et al., 2012) (see Table 2 for the detailed measurements).

\section{Artefactual and faunal remains in deposits}

The deposits were disturbed by digging and refilling of the graves, so we only describe the main traits of the lithic artefacts and faunal remains present in the deposits (see Celiberti et al., 2018 and Frère et al., 2018 for a full description of this material). 
A total of 1,297 lithic pieces referenced in three dimensions and 847 pieces smaller than $1 \mathrm{~cm}$ were retrieved from sediment layers intersected by the graves. Several chaînes opératoires, essentially related to shaping, and débitage operations appear to have been conditioned by the morphology (pebble or block) and quality of the raw material (fine-grained sandstone, silicified limestone or quartz) (Celiberti et al., 2018); knapping operations appear to have been conducted without production standardisation from a technological perspective. The observed lack of homogeneity of the raw materials, the low number of unifaces and tools on split cobbles, as well as the presence of composite tools associated to asymmetric pieces or limaces, suggest that this material is a regional variant of Hoabinhian, as at Moh Khiew site in southern Thailand (Auetrakulvit et al., 2012).

A total of 31,699 faunal remains (Table 3) were uncovered in these deposits, with a prevalence of bone splinters and a few teeth. Taxonomical diagnosis very rarely obtained species identification and the Number of Identified Specific Parts (NISP) was only 4,256. Different taxonomic ranks have been identified: several Bovids and Cervids, rare Suids and some Carnivores, Rhinoceroses and Primates. The fairly large herpetofauna included varanids, turtles and snakes. Freshwater crabs, land snails and freshwater mussels have also been found in large numbers at Doi Pha Kan.

The observed fauna is indicative of a forest environment and the anatomical distributions of Cervus and Bos remains suggest that butchering was consistently conducted outside of the rock-shelter, similar to the practices identified at Laang Spean cave, Cambodia (Forestier et al., 2015). As a large number of phalanges are burnt, fire could have been used to free phalanges out of ligaments to reach the bone and/or marrow (Marean and Cleghorn, 2003). It is also possible that ligaments, tendons, and skins, or even bones, were used for non-food purposes. The faunal remains indicate that people at Doi Pha Kan were hunter-gatherers (Frère et al., 2018).

\section{Burial descriptions}

In this paper the three burials, dpk E-5, dpk D-4 and dpk DE-5, are described using an archaeothanatological approach. The former two have been briefly detailed in the previous work of Imdirakphol and colleagues (2017).

The grave dpk DE-5 (Fig. 4) was found $40 \mathrm{~cm}$ under the soil surface. The skeleton was very badly preserved; the brittle bones crumbled into dusty sediments when displaced. An adult individual was lying on its left side, and the whole skeleton was partially concealed under a layer of red ochre powder. The grave was aligned in an east-west direction. The right upper limbs were not preserved and the lower limbs were flexed. The left upper limbs were flexed, the elbow lowered down to the level of the pelvis and the wrist was at the level of the plexus. The skull was resting on its left side facing southwards. A mortar filled with ochre powder was spilled directly above the individual's humerus (Fig. 5). There was no evidence for any structure or container associated to the body however a nondurable wrapping, such as a fibrous wrapping or a basket, could have been present. The individual was determined to be male with a $99 \%$ probability (Table 2) with a height of $178.9 \pm 3.5 \mathrm{~cm}$ and $177 \pm 3.5$ $\mathrm{cm}$ based on the maximal length of his femurs, according to the methods of Mahakkanukrauh et al., (2011) and Pureepatpong et al., (2012), respectively.

The top of the grave dpk E-5 (Fig. 6) was identified by a circle of calcareous blocks $85 \mathrm{~cm}$ below the soil surface. Ten centimetres below the bottom of these blocks was a grave aligned in a northeast-southwest direction. The skeleton was badly preserved and, covered and surrounded by ochre, and by charcoal on the lower limbs. The individual was lying on its right side with its skull facing west. Only the upper branch of the mandible was preserved, but the temporo-mandibular articulation indicated that the mouth was open. The right lower limbs were fully flexed and the left were not preserved. The right knee was at the level of the mandible. The right upper limbs were flexed with a pronation of the wrist. The right hand was not preserved, but the wrist was at the level of the left rib 
cage. Of the left upper limbs only the humerus was present, and its posterior side indicated a complete axial rotation. The humeral head was off-centre compared to its normal anatomical position. The vertebral column and the legs of the individual seem to preserve their initial flexed position, while the movement of the upper limbs suggests that some vacuum existed during the decay of the body. We suggest that the weight of the blocks used to close the grave may have contributed to such a movement during the decay of the flesh, but it should be noted that the complete left lower limb was not preserved. There was also no evidence for any structure or container associated to the body.

The scoring of the right coxal bone indicated the individual was male with a $99.99 \%$ probability (Table 2). This individual's height was estimated to be $174.9 \pm 3.5 \mathrm{~cm}$ and $176.2 \pm 3.5 \mathrm{~cm}$ according to the methods of Pureepatpong et al. (2012) and Mahakkanukrauh et al. (2011), respectively.

This grave was also characterized by the presence of partially sooty deposits and pockets of ochre powder. The grave was rich in offerings (Fig. 7). An adze and an axe with polished cutting edges were located on the left rib cage; a pestle was found at the back of the vertebral column and a second, smaller pestle was present near the coxal bone. A pendant, made out of a bivalve shell, as well as a frontal bone and a shaft of a long bone (Muntiacus muntjak) were placed between the leg and thigh bones of the individual. A perforated stone, another complete mollusc shell, and a lump of ochre were located near the foot of the individual.

The grave dpk D-4 (Fig. 8) was found $30 \mathrm{~cm}$ below the bottom of the grave dpk DE-5. Calcareous blocks partially covered the body of an adult individual. A perforated stone, broken into two pieces, was located on top of these blocks. The grave was oriented southwest-northeast with the individual's head positioned towards the southwest. A large, rounded stone tinged with red ochre was underneath the right side of the skull which lay on its left side facing northwards. The body appears to have been interred on its front. The left scapula appears on its posterior face. The left elbow was flexed at a right angle, with the forearm under the vertebral column and on top of the shaft of the left femur. The left humerus was attached to the left rib cage. The bones of the left hand were under the proximal part of the left tibia. The right humerus was on the radius and ulna with a supination of the wrist indicating that the right hand had originally been placed near the base of the skull. The right foot was exposed on its lateral side and the left foot on its medial side, both at the level of the hipbone. Both the right parietal and temporal bones were driven in by a red ochre-tinged stone, and a second stone coated with a red colour was lying to the right side of the individual (Fig. 9). A subtriangular-shaped perforated stone was located under the lower-half of the shaft of the right tibia, in association with a red ochrecoloured grindstone. A tortoise shell was lying under the individual's feet, which were covered by a red-coated calcareous block suggesting that the body was at least partially sprinkled with red ochre powder. The position of the body, with no evidence for any other structure or container associated to the body, suggests a grave with the body buried directly in the deposits under the blocks.

The scoring of the left coxal bone indicated the individual was male with a $99.84 \%$ probability (Table 2) with an estimated height of $173.5 \pm 3.5 \mathrm{~cm}$ and $172.5 \pm 3.5 \mathrm{~cm}$ according to Mahakkanukrauh et al. (2011) and Pureepatpong et al. (2012), respectively.

In summary, although the three individuals were all buried in a "flexed" position according to the current literature, there are some notable differences between the three cases (Table 1). In contrast to DE-5, individuals dpk E-5 and dpk D-4 were buried with numerous offerings and block covers, and their lower limbs were in a fuly flexed position. However, individual dpk D-4 was buried on the front, which was not the case for dpk E-5.

The relative spatial distribution of the graves raises the question of grave depth, which is a recurrent issue in burial excavation. At Doi Pha Kan, the graves intersect archaeological layers rich in bone remains and lithic artefacts (average density of remains $=3,109$ per $^{3}$ of sediment). The deposits are loose with a natural tendency to collapse, so it is unlikely that the burials were dug deeply: a burial 
deeper than $90 \mathrm{~cm}$ would have been extremely unstable and unpractical. Indeed, the big calcareous blocks sealing the lower graves (i.e. dpk D-4 and dpk E-5) suggest a maximum depth of about $40 \mathrm{~cm}$. The deepest part of the upper burial did not intersect the two lower graves; the bottom of the upper grave was found $65 \mathrm{~cm}$ below the shelter's floor surface, i.e. $15 \mathrm{~cm}$ above the top of the middle and lower graves (Fig. 10).

\section{Dating of burials}

Our understanding of the evolution of Southeast Asian mortuary practices depends on the accurate and precise dating of burials. Currently, there is a scarcity of evidence supporting regional sequences and difficulty in interpreting radiocarbon dates from many mortuary sites (Higham and Higham, 2009; White, nd). Direct dating of two of the three Doi Pha Kan burials, i.e. dpk E-5 and dpk D-4, was recently published in Imdirakphol et al. (2017). Here we also use dating on bone apatite due to the lack of preserved bone collagen in the human remains to date burial dpk DE-5.

As post-mortem chemical exchanges between bone and embedding sediment are limited, the structural carbonate present in the mineral fraction of the bone (bioapatite) can be dated (Zazzo and Saliège, 2011). The humid tropics are, a priori, suboptimal environments for this type of dating because water is likely to promote carbon exchange via bicarbonate dissolution between the bone and sediment to be tested. Thus multiple samples from different materials (charcoal, shell, bone and tooth apatite) collected in the grave dpk E-5 were dated to assess the relevance of dating bone apatite samples. After preparation at the MNHN Radiocarbon Laboratory following the protocols described in Zazzo (2014), the carbon dioxide emissions resulting from either the combustion or hydrolysis of purified samples were sent to the Artemis AMS facility at Saclay for graphitisation and radiocarbon measurement.

The dates obtained for the three burials ranged from $11,170 \pm 40$ to $12,930 \pm 50 \mathrm{BP}$ (Table 4). Dates were consistent for charcoal $(12,930 \pm 50 \mathrm{BP})$ and shell $(12,920 \pm 80 \mathrm{BP})$ and similar to that obtained for the femoral shaft of individual dpk E-5 (12,540 $\pm 50 \mathrm{BP})$. It is probable that the slightly earlier values obtained from biopatite are related to the influence of diagenesis; thus the age estimates should be considered as minimum values. Comparing the dates of the femoral shafts in burials dpk DE5 (11,955-11,641 BC cal) and dpk E-5 (13,169-12,462 BC cal) with burial dpk D-4 (12,719-12,081 BC cal) considering a similar influence of diagenesis in such a restricted area, and including the stratigraphy and location of the three graves (Fig. 10), two phases might be present: (1) an older phase with hyperflexed bodies associated (dpk E-5 and dpk D-4) with the use of blocks and many offerings, including perforated stones, and (2) a more recent phase without block covers, only rare offerings, and a flexed (not hyperflexed) position of the body (dpk DE-5).

\section{Discussion}

Archaeologists in Southeast Asia acknowledge that there is a lack of established cultural and chronological reference systems. Compared to other regions this delay is due to the low number of researchers focusing on this region and its geopolitical history. Nevertheless, the origin of populations has been debated for more than a century, but no consensus has been made on the relative importance of successive migrations from external sources versus indigenous continuity through time (Bellwood, 2018). Renewed bio-anthropological studies (Matsumura and Oxenham, 2014 ; Matsumura et al. 2015) have been conducted to model the regional population, but they have highlighted two fundamental problems with the regional continuity model: (1) evidence derives from present-day population datasets ; and (2) there is a lack of samples dating prior to the agriculturally driven population dispersals of the Neolithic. However, Matsumura et al. (2015) give evidence for a lineage: north Vietnamese populations from the Bac Son culture (ca 7000 BP) to the Da But culture (ca $6000 \mathrm{BP}$ ), as direct descendants of Hoabinhian foragers. 
Due to recent technical advances in the analysis of ancient whole-genome DNA from archaeological skeletons in tropical region (Orlando et al. 2015), the affinity of different archaeological individuals has been established (Bellwood 2018) suggesting a more complicated scenario of population movements in Southeast Asia than previously established. However, these undeniable advances can only be validated if the dating and, more generally, the archaeo-chrono-cultural foundation is reliable.

"Flexed" and "extended" burials are common terms in regional archaeo-anthropological literature. Indeed, the start of the Neolithic period in Southeast Asia was fixed according to these two simplified categories (Bellwood, 1993; Higham 2002; Higham and Higham, 2009; Rispoli, 2007); anthropological series formerly excavated were a posteriori attributed to Neolithic or to older tombs (cf Bulbeck nd use a stable citation). However, this categorisation is an over-simplification which neglects the distinct funerary practices that our review has highlithed (Table 1). Significant cultural differences might be identifiable with a more detailed archaeo-thanatological approach (see Tayles et al., 2015). In future studies, the term "flexed" must be further differentiated to account for the degree of flexion of the limbs: individuals lying on their back with flexed limbs, and individuals lying on one side with flexed upper and lower limbs. The Chinese burials reported by Rispoli (2007) constitute to understanding the origin of funerary practices and populations in Mainland Southeast Asia. However, the debate raised by Higham (2002) on the advent of a Neolithic population and variation in prior funerary practices can only be resolved if these all the burial practices are well-documented i.e. described following archaeo-thanatologal approach. We have already discussed the limitations of using the "extended/flexed" position as a chronological marker (Zeitoun et al., 2012, 2013). While "flexed" burials were progressively replaced by "extended" burials in the Neolithic period, isolated "flexed" burials seem to have persisted, suggesting that: (1) the hypothesis of a "new Chinese fashion" of inhumation requires further investigation; and (2) there is still a lack of secure chrono-cultural markers and detailed descriptions of burials in Southeast Asia.

In addition to this chronological attribution, burial type has been tied to specific populations. For example, the analysis of Neolithic and Metal Age sites (Higham and Higham, 2009) suggested that the replacement of "flexed" burials by "extended" burials were a marker of "Chinese Neolithic invaders" within the "indigenous Southeast Asian hunter-gatherers". However, this classification should be refined to include: (1) the archaeo-thanatological approach within and between cemeteries (see Oxenham, 2000; Hiep and Huffer, 2015); and (2) the occurrence of "extended" burials in the ancient period, including groups of graves that do not constitute real cemeteries. Without these data, current attributions are problematic.

While distinct phases in Mainland Southeast Asian Neolithic burial practices have been identified based on the general spatial arrangement of graves (depth, orientation, and superimposition) and on the uncovered artefacts (Higham and O'Reilly, 2004), additional features may provide critical evidence. Burial modalities, i.e. whether the body was interred directly in the soil, in a coffin, or wrapped in fabric, represents important and under-evaluated aspects of funerary practices that are rarely included in Southeast Asian archaeological studies (Willis and Tayles, 2009; Harris and Tayles, 2012; Zeitoun et al., 2012; 2013). The three adult individuals of Doi Pha Kan provide information which, when taken individually are not unique, even for Southeast Asia. Similar to the single burial at Ban Tha Si, the three individuals of Doi Pha Kan have a tall stature. Tayles et al. (2015) noted that tall stature is quiet rare for this period in Southeast Asia, following observations at the Da But cultural site of Con Co Ngua in Vietnam and at Pha Phen in northern Laos. Along with other criteria, this trait could be used as a bioanthropological marker to identify specific populations, for example at Xom Trai an individual with an estimated stature of $168 \mathrm{~cm}$ was found buried in a Hoabinhian layer (Viet, 2015).

Considering the burial offerings at Doi Pha Kan, the ground edge adze and axe are similar to 
discoveries made by Mansuy $(1909,1924)$ and Colani (1930) in Vietnam, and a number of other sites in Vietnam (Ha, 1980) and south China (Rispoli, 2007). At Liyuzui in the Guangxi province for period I (9000-8000 BP), several sites are characterised by "flexed" burials associated with polished stone axes and perforated stones (Rispoli, 2007). In Southeast Asia the occurrence of perforated stones seems to be restricted to a belt (Fig. 1) that encompasses Myanmar, northern Thailand, Vietnam and southern China, excluding southern areas and insular Southeast Asia (Imdirakphol et al., 2017). Nevertheless the question arises as to whether this area is a cultural phenomenon or due to lack of documentation.

Sealing blocks are rarely observed to cover burials in Southeast Asia. The use of blocks to cover "crouched" burials in the Zengpiyan cave (northern part of Guangxi province) from period IV (12,000 - 8000 BP) (Rispoli 2007) is similar to the case of Du Sang where individuals were buried on their backs with flexed lower limbs, associated to Hoabinhian deposits (Viet, 2015). At Doi Pha Kan covering blocks were also present, but the individual dpk D-4 was buried on the front looking down and individual dpk E-5 was lying on its side. Doi Pha Kan sheds light on a specialcific regional anthropo-cultural diversity that has not been previously recognized, due to the scarcity of data and the lack of appropriate methodology for excavating and analysing such burials. At the regional level, research needs to focus on the possible relationships between the Chinese "crouched" burials of the Lingnan region (Guangxi and Gandong provinces), the Lampang province in north Thailand and the Da But squatting burials of Vietnam.

According to our regional review, albeit being based on rare available data and the absence of precise descriptions or illustrations of skeletal remains historically attributed to the Neolithic, "Mesolithic", Palaeolithic, Hoabinhian or Bacsonian (cf Mansuy, 1924; Mansuy and Colani, 1925; Mansuy, 1925a, b, c; Colani, 1927a, b, 1930), Hoabinhian burials correspond to either: individuals lying on their back with extended upper and lower limbs ("extended" burials), individuals with some degree of flexion of the limbs, or individuals lying on one side with some degree of flexion of the limbs.

\section{Conclusion}

Our findings at Doi Pha Kan echo the remark of Higham (2013) that "the Dingsishan sites in China and those of the Da But and Bacsonian in north Vietnam are so similar that they must have been developing in tandem". Our research complements the observations of Higham by broadening the geographic and temporal framework. In particular, the archaeological burials and associated dates in the Phratu Pha valley indicate that this mountainous region of Thailand has been inhabited for a long period that spans as far back as 13,000 BP at Doi Pha Kan, or between 11,000 to 7000 BP at Ban Tha $\mathrm{Si}$. Hyper-flexed burials, tall individuals, covered graves, offerings including perforated stones and edge ground adzes seem, however, to be limited to the geographical region usually attributed to the Hoabinhian (cf Imdirakphol et al., 2017).Our archaeo-thanatological approach identifies evidence of cultural diversity in what has been previously seen as Hoabinhian uniformity.

It is difficult to conceive that there was no variability in burial practices in Mainland southeast Asia for 30,000 years; it is likely that this is an artefact of data scarcity and research gaps. Variability needs to be assessed by further bioanthropological studies, such as those already initiated by Matsumura and Hudson (2005), those mentioned by Belwood (2018) for whole-genome DNA, and also on the lithic material. Archaeological research must continue to build regional chrono-cultural reference frameworks in Mainland Southeast Asia to give historical meaning to the results obtained by biological studies. 


\section{Acknowledgments}

This work was undertaken under the authority of the $6^{\text {th }}$ Archaeological Division of Fine Arts Department, Nan Museum, Thailand. We are grateful to Chaturaporn Tiamtinkrit and Chawalit Khaokhiew for their support. We would like also to thank the Commission Consultative des Fouilles Archéologiques du Ministère Français des Affaires Etrangères et du Développement Internationale and Chidpon Jantarawaranyoo from SedcoForex Internationational Inc. for their support. We also thank Becky Coles for her help with English, Salvador Bailon for his help in the anatomical study of reptiles and two anonymous reviewers for their constructive comments. Radiocarbon measurements were performed at the Artemis facility by the team of LMC14 with the support of the CNRS-InSHS and the program ATM Emergence of Museum national d'Histoire naturelle, Paris.

\section{Figure captions}

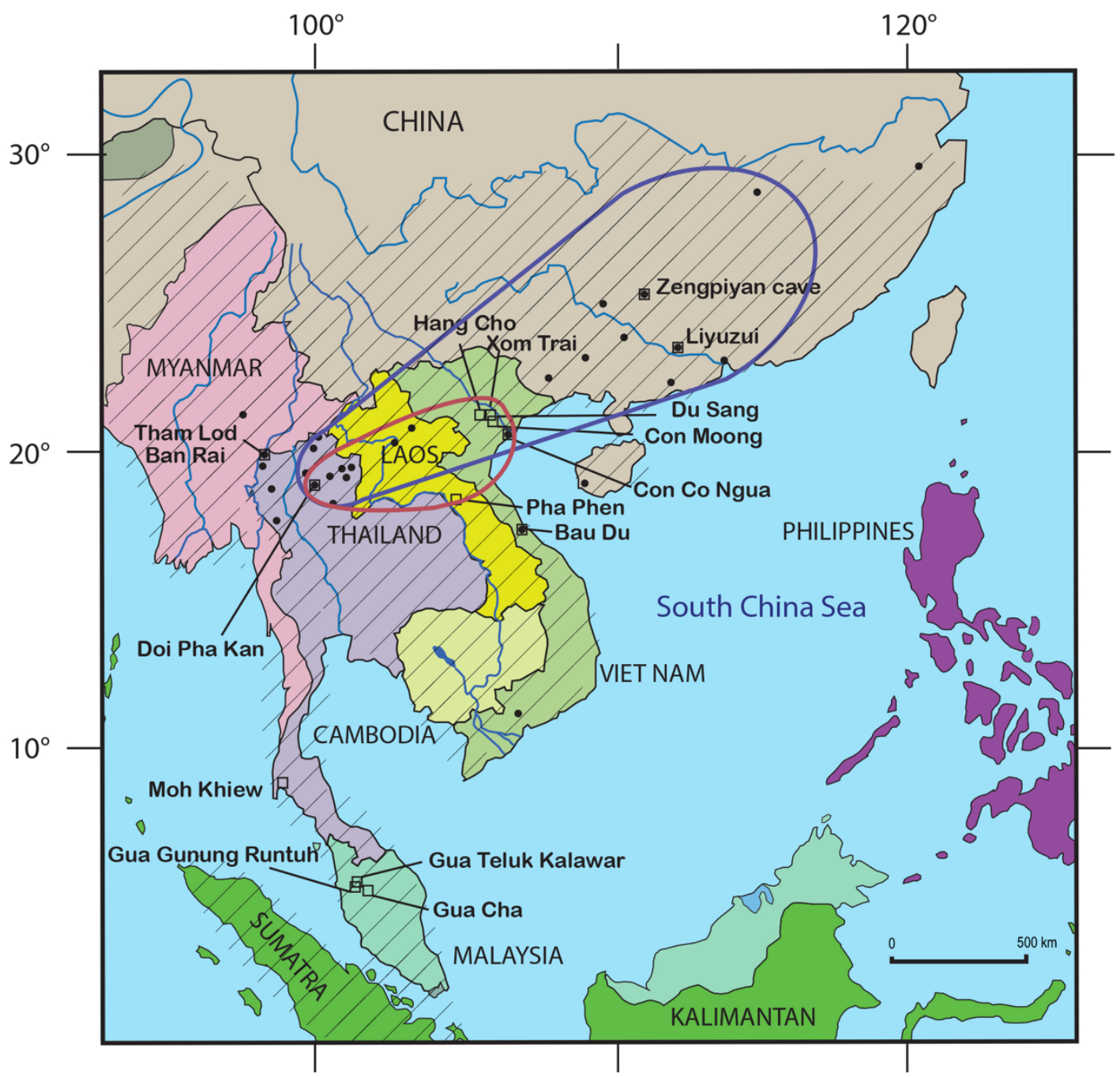

Figure 1 Map of the sites indicated in the text with indication of Hoabinhian cultural area (hatched surface) with sites including perforated stones (point), flexed burial (square)), "tall people" potential area (red line), the covered graves potential area (blue line), modified from Imdirakphol et al. (2017). 


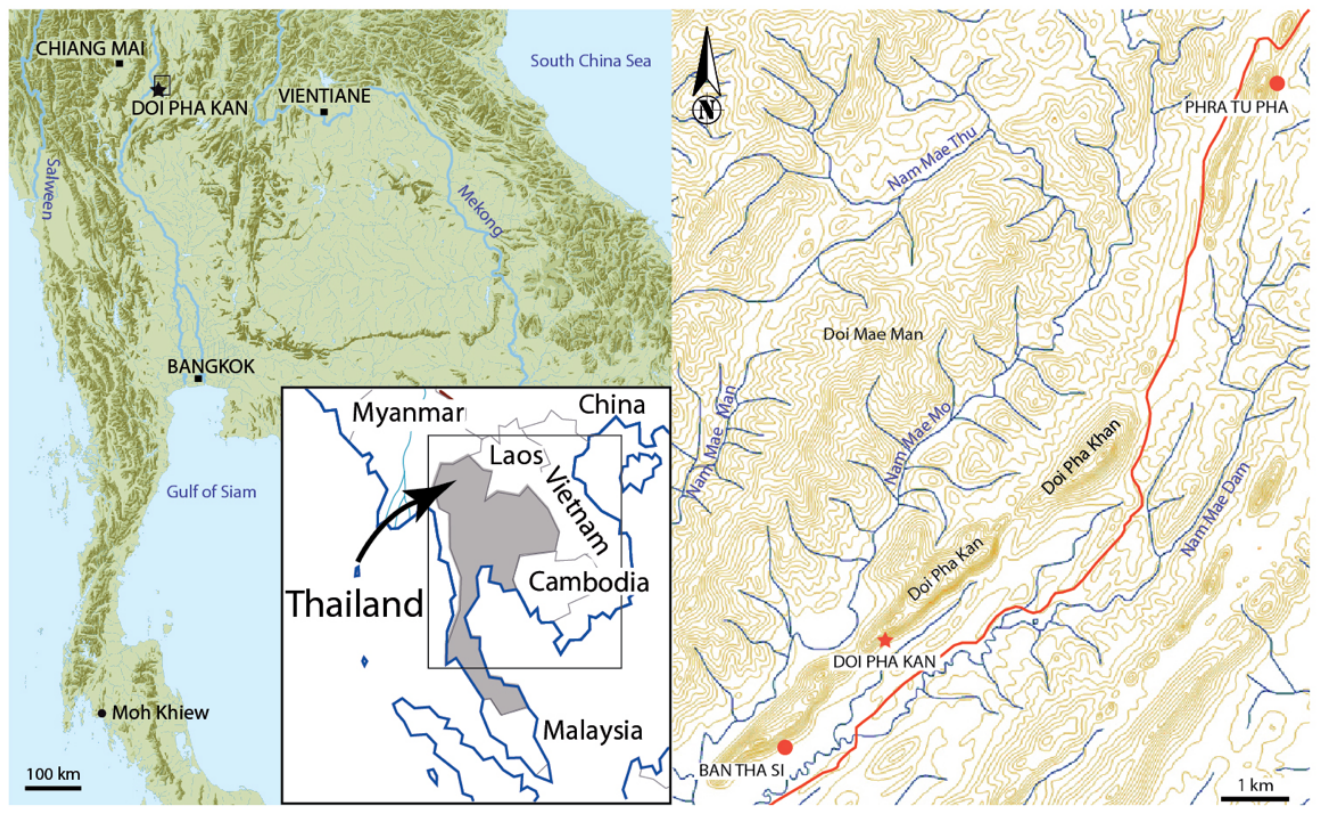

Figure 2

Location of Doi Pha Kan site.

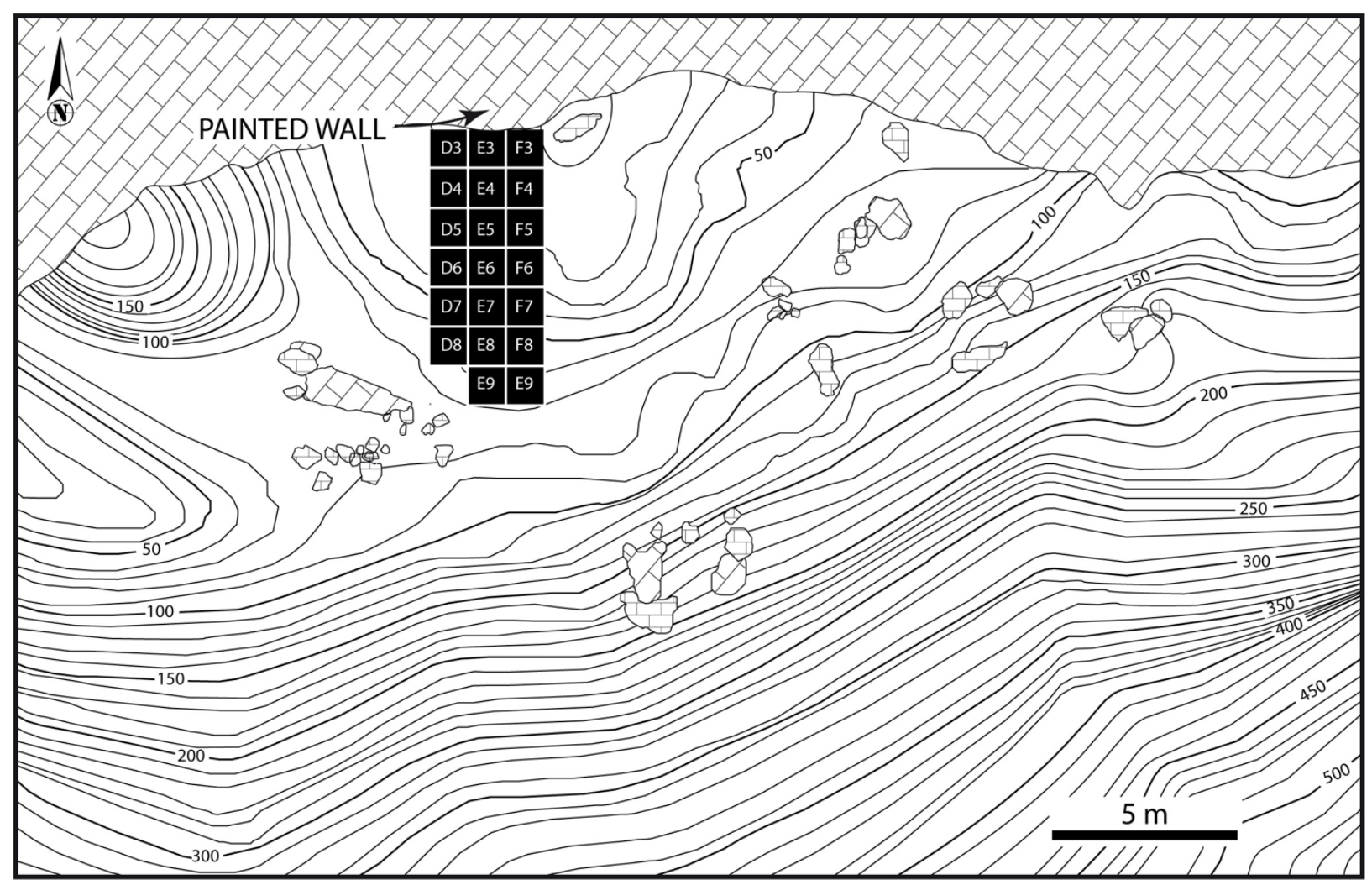

Figure 3

Location of the excavated area at Doi Pha Kan 


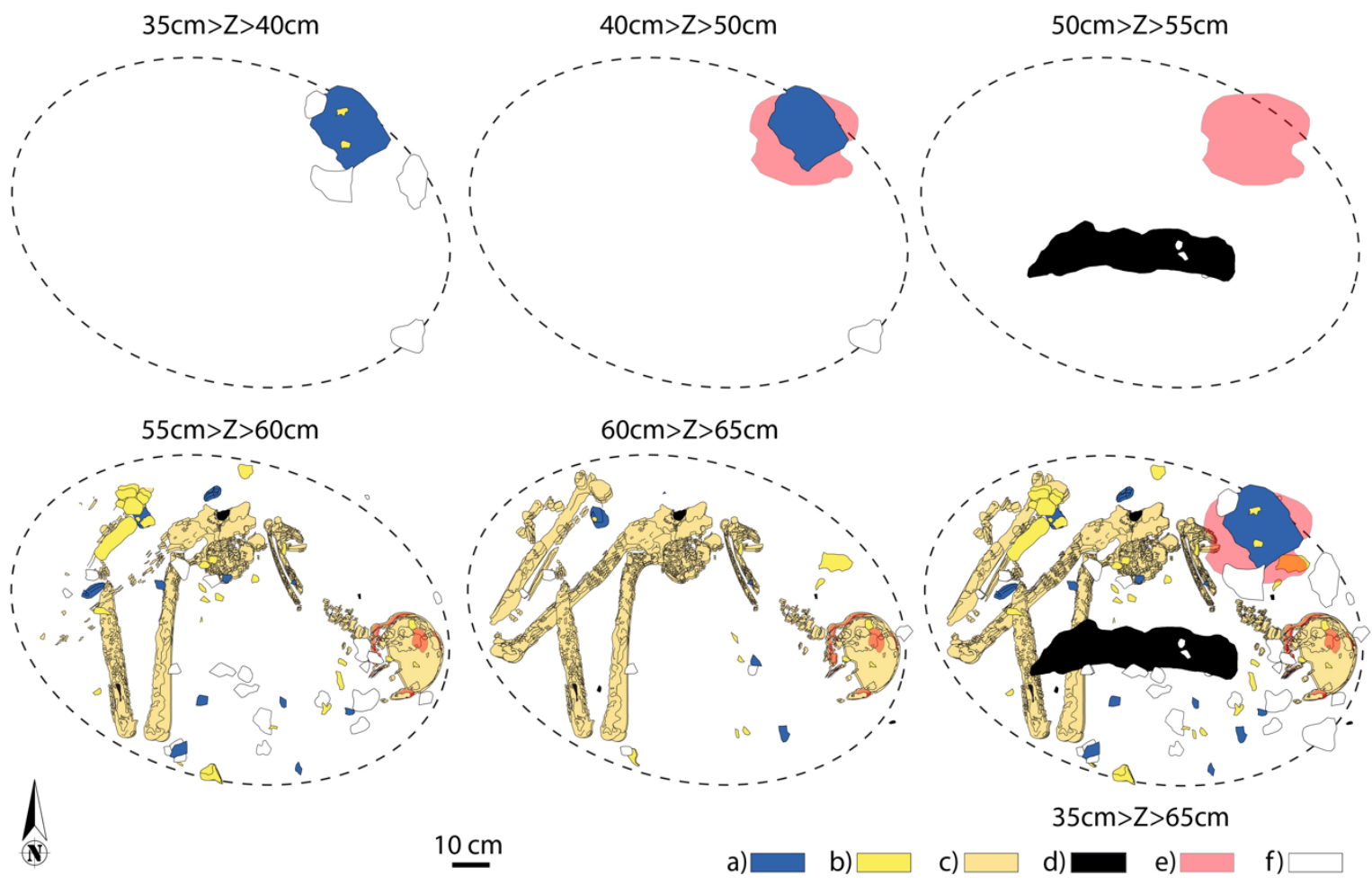

Figure 4

Burial $\mathrm{n}^{\circ} 1$ (dpk DE-5): a) lithic artefacts, b) animal bones c) human bones, d) charcoals, e) ochre, f) limestone.

\section{Figure 5}
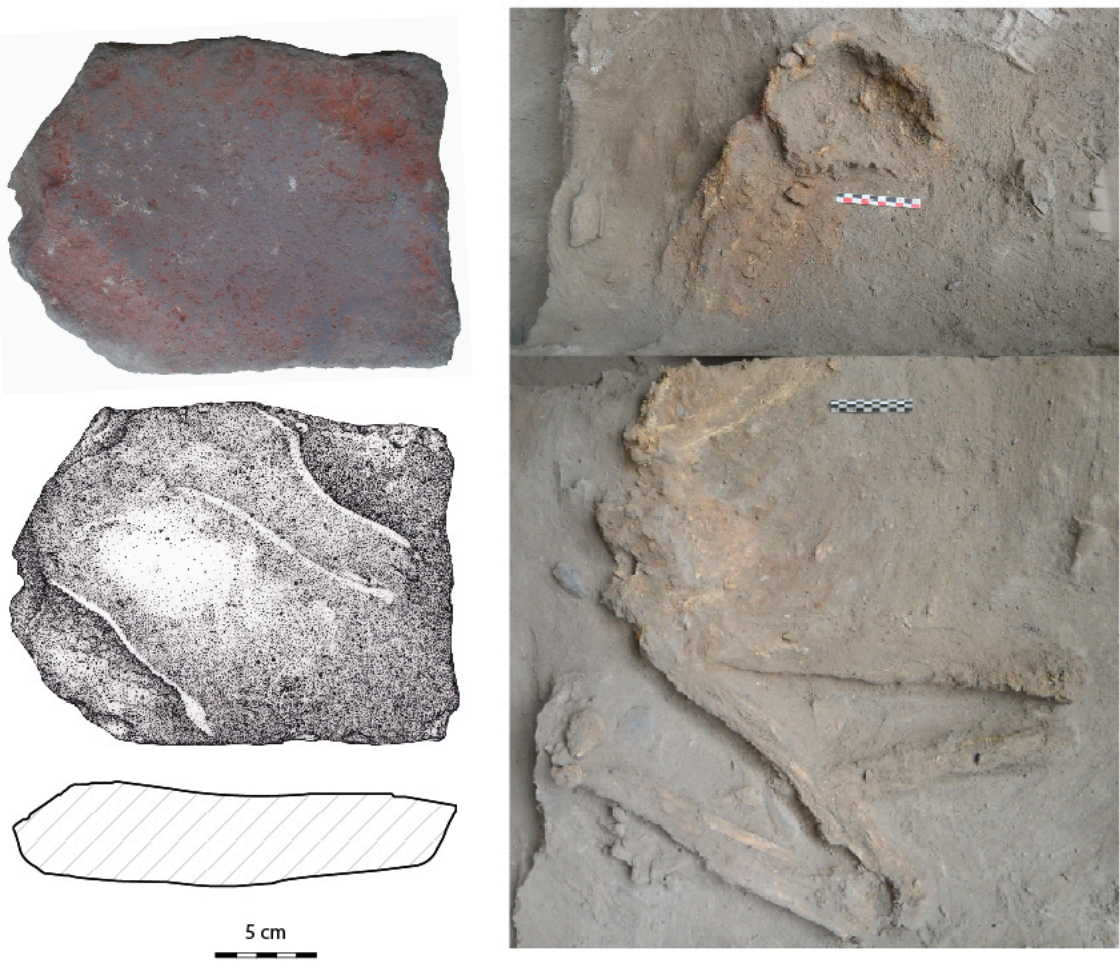

Burial $\mathrm{n}^{\circ} 1$ (dpk DE-5) with the mortar filled with ochre powder. 

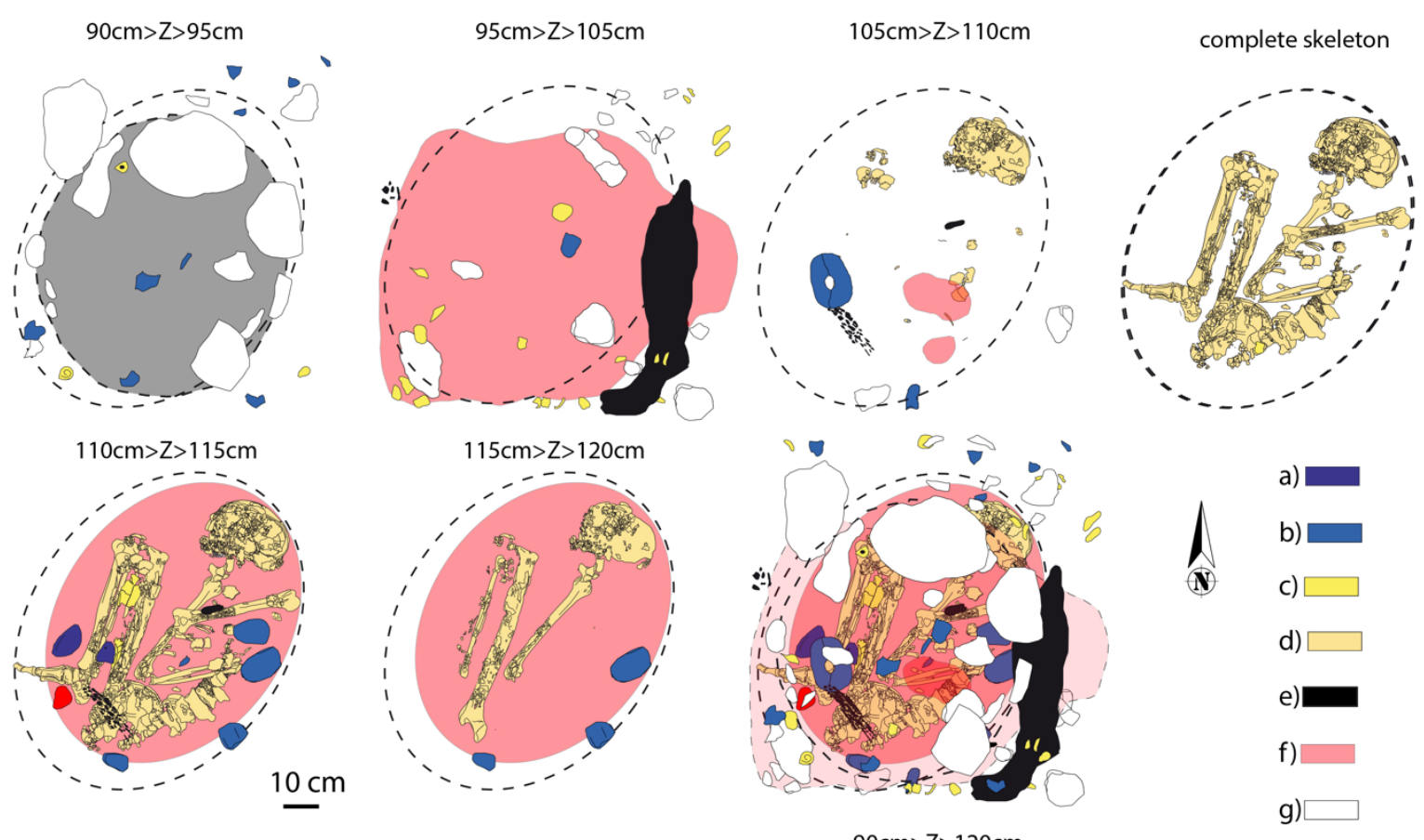

\section{Figure 6}

Burial n`2 (dpk E-5): a) shell, b) lithic artefacts, c) animal bones d) human bones, e) charcoals, f) ochre, g) limestone.

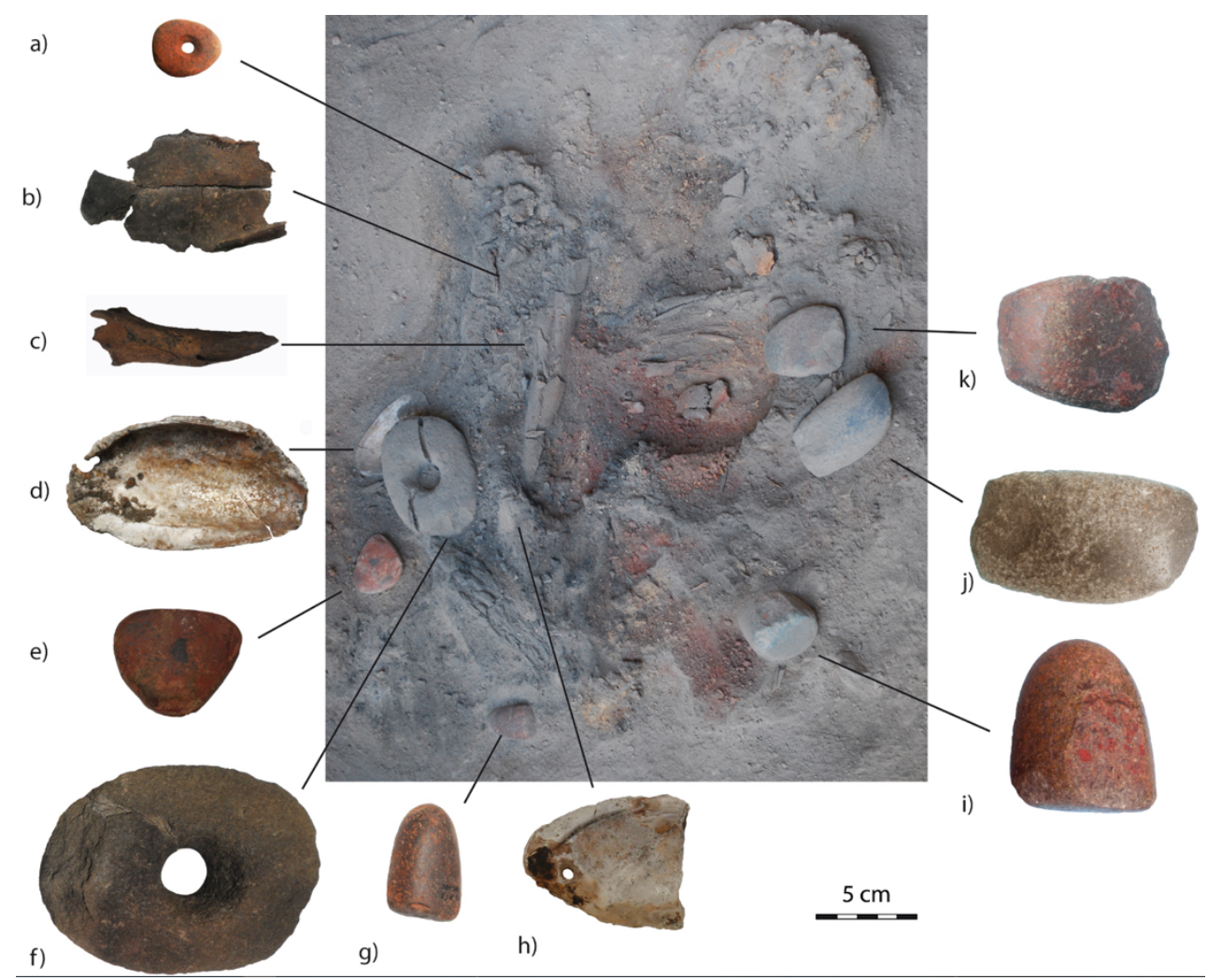

\section{Figure 7}

Offerings of burial n² (dpk E-5): a) amulet, b) c) Muntjac remains, d) shell, e) lump of ochre f) perforated stone, $\mathrm{g}$ ) micro pestle, h) shell, i) pestle, $\mathrm{j}$ ) ax, $\mathrm{k}$ ) adze. 

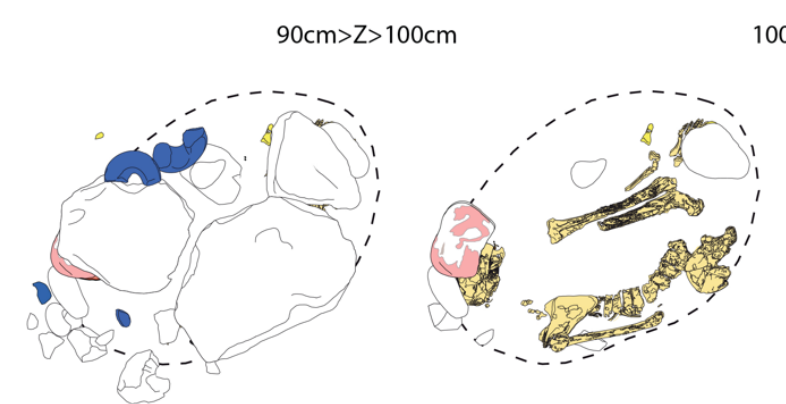

$100 \mathrm{~cm}>\mathrm{Z}>105 \mathrm{~cm}$

complete skeleton
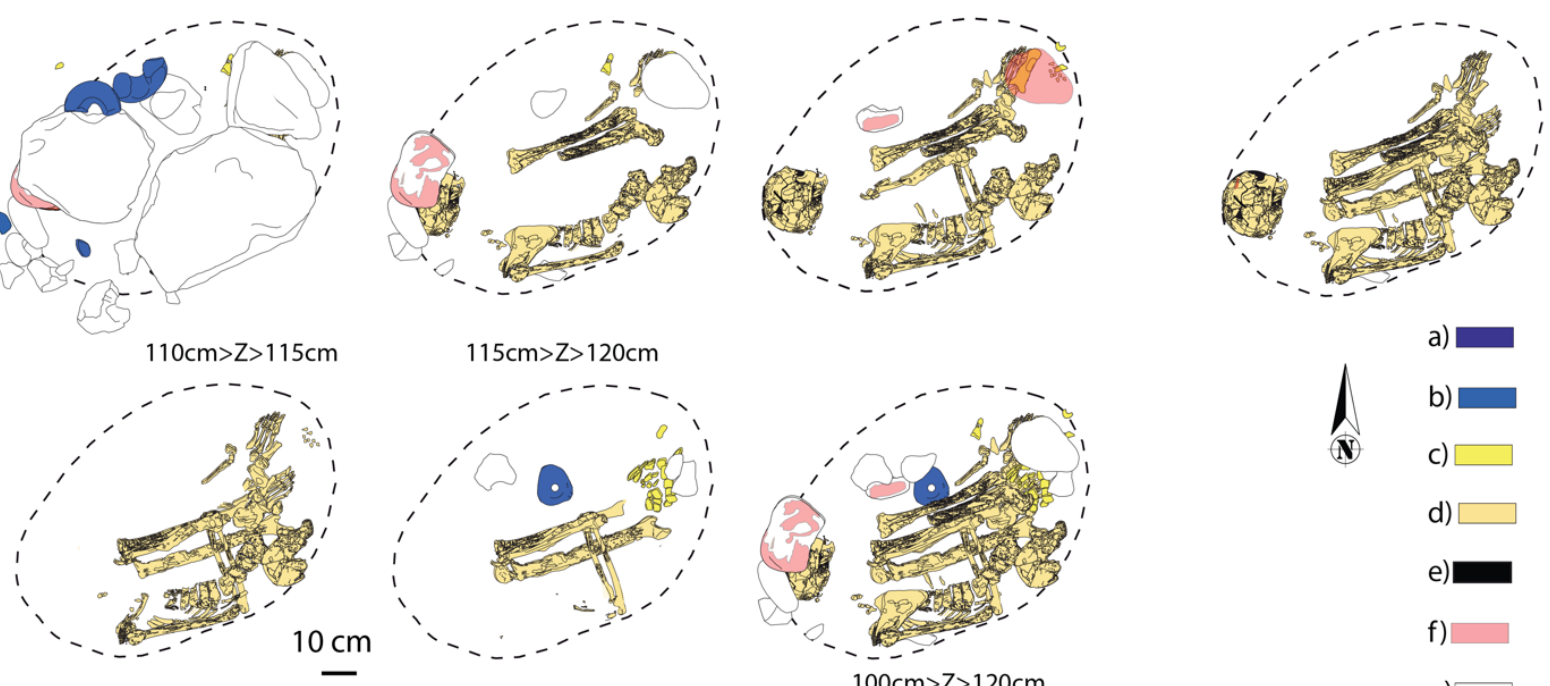

$115 \mathrm{~cm}>\mathrm{Z}>120 \mathrm{~cm}$
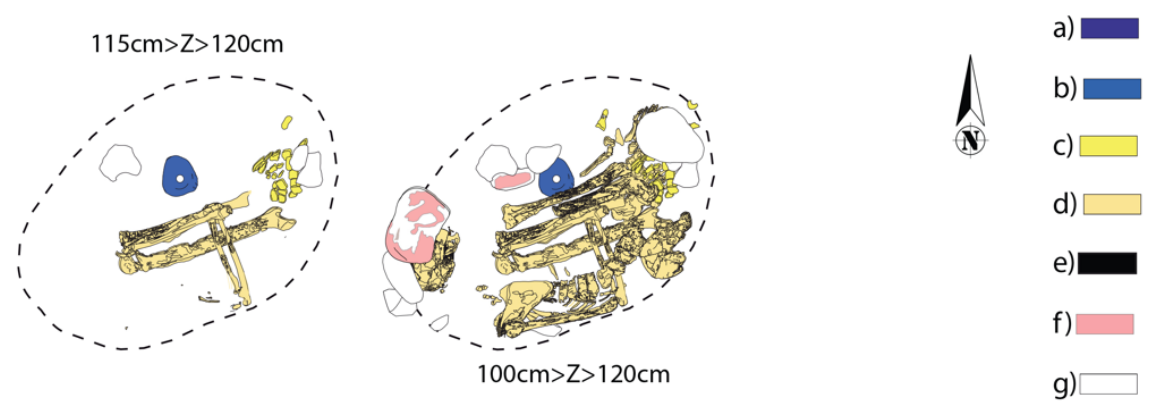

Figure 8 Burial n³ (dpk D-4): a) shell, b) lithic artefacts, c) animal bones d) human bones, e) charcoals, f) ochre, g) limestone.
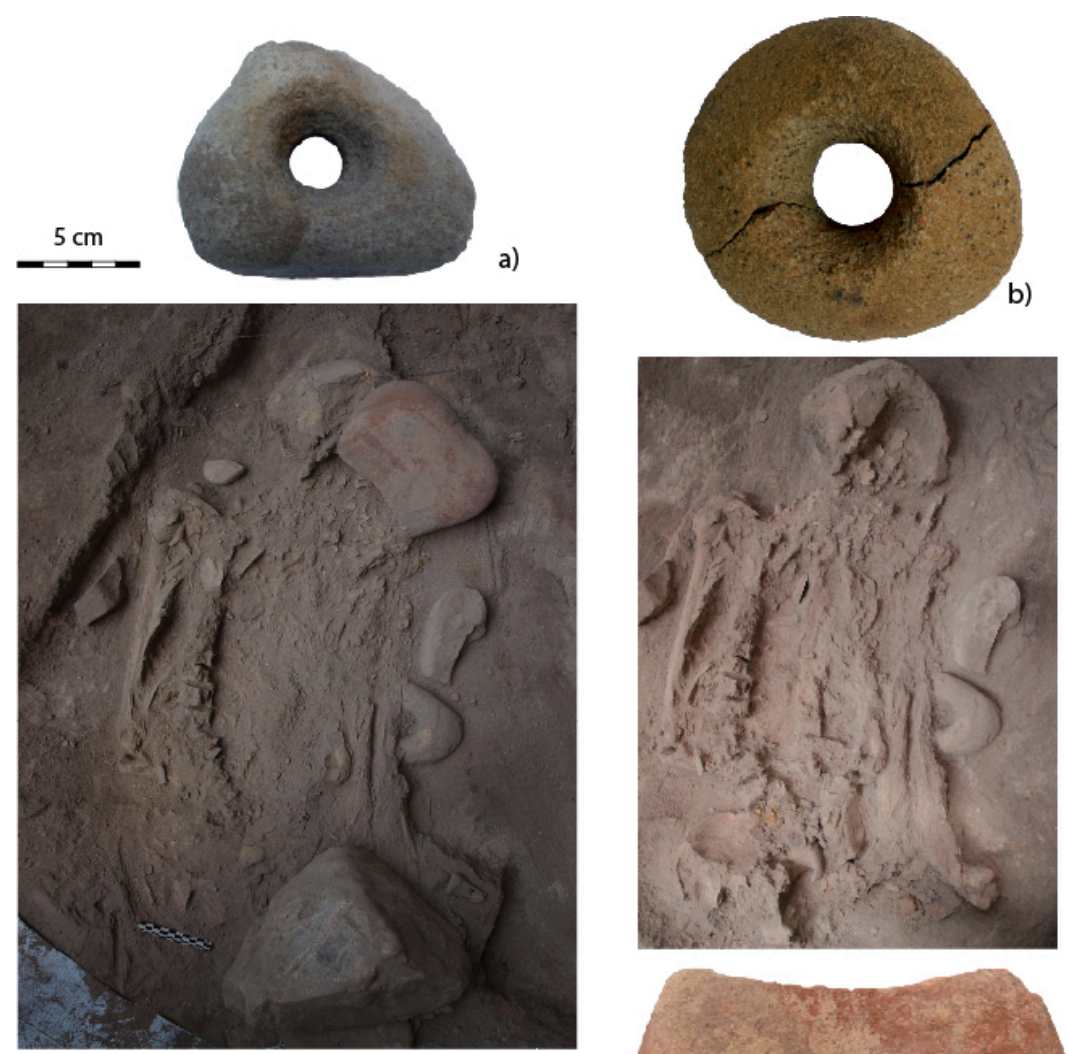

Figure 9

Offerings of burial $\mathrm{n}^{\circ} 3$ (dpk D-4): a) ochre tinged stone, b) perforated stone, c) red colored ground stone, d) perforated stone.
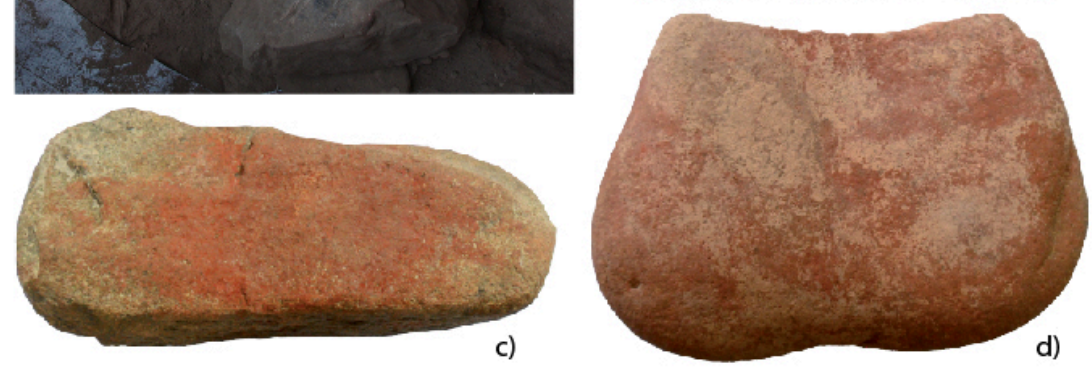


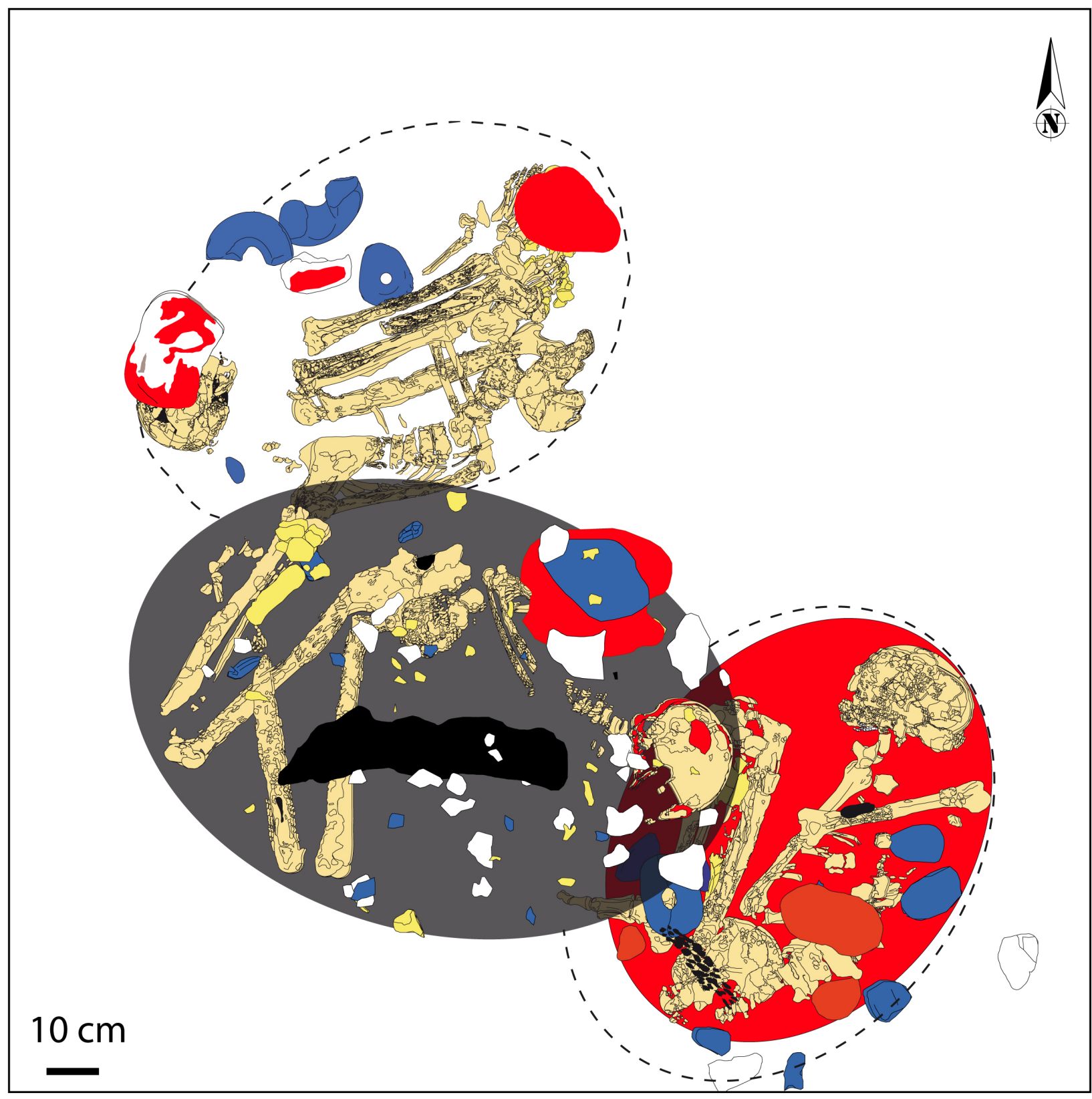

a) $\square\left(\begin{array}{llll}\text { b) } \square \text { c) } \square \text { d) } \square \text { e) } \square(\text { f) } \square(\text { g) } \square \square\end{array}\right.$

Figure 10

Superposition of the burials.

a) shell, b) lithic artefacts, c) animal bones d) human bones, e) charcoals, f) ochre, g) limestone. 


\begin{tabular}{|c|c|c|c|c|c|c|c|c|c|}
\hline \multirow[t]{2}{*}{ Site } & \multirow[t]{2}{*}{ date BP } & \multirow{2}{*}{ direct/undirect } & \multirow{2}{*}{ references } & \multirow{2}{*}{$\begin{array}{c}\text { associated } \\
\text { material }\end{array}$} & \multirow{2}{*}{$\begin{array}{l}\text { archaeological } \\
\text { context }\end{array}$} & \multicolumn{3}{|c|}{ position of the body } & \multirow{2}{*}{ references } \\
\hline & & & & & & $\begin{array}{l}\text { lying on the side } \\
\text { or on the back }\end{array}$ & upper limb & lower limb & \\
\hline \multicolumn{10}{|l|}{ Tham Lod } \\
\hline burial 1 & $12100 \pm 60$ & soil beneath & Shoocongdej, 2006 & hammer stone & Hoabinhian & too much incomplete & - & extended & Shoocongdej, 2006 \\
\hline burial 2 & $13640 \pm 80$ & charcoal & Shoocongdej, 2006 & ring of large cobble & Hoabinhian & & right arm extended & fully flexed & Shoocongdej, 2006 \\
\hline \multicolumn{10}{|l|}{ Ban Rai } \\
\hline burial 1 & $9720 \pm 50$ & sedimentt & Pureepatpong, 2006 & none & Hoabinhian & on the back & right arm extended & flexed & Pureepatpong, 2006 \\
\hline \multicolumn{10}{|l|}{ Ban Tha Si } \\
\hline burial 1 & $7047 \pm 53$ & direct dating & Zeitoun et al., 2013 & none & Hoabinhian & on the right side & flexed & flexed & Zeitoun et al., 2013 \\
\hline \multicolumn{10}{|l|}{ DOI PHA KAN } \\
\hline dpk DE-5 & $11895 \pm 45$ & direct dating & this study & mortar filled with ochre powder & Hoabinhian & on the left side & left flexed & flexed at $90^{\circ}$ & this study \\
\hline dpk E-5 & $12540 \pm 50$ & direct dating & Imdirakphol et al., 2017 & $\begin{array}{l}\text { circle of blocks,ochre powder, adze, } \\
\text { axe, pestles, pendant, perforated } \\
\text { stone, faunal offerings }\end{array}$ & Hoabinhian & on the right side & right flexed & right fuly flexed & Imdirakphol et al., 2017 \\
\hline dpk D-4 & $12340 \pm 50$ & direct dating & Imdirakphol et al., 2017 & $\begin{array}{l}\text { cover of blocks, ochre powder, } \\
\text { grinding stone, perforated stones }\end{array}$ & Hoabinhian & on the stomach & left at $90^{\circ}$ & fully flexed & Imdirakphol et al., 2017 \\
\hline \multicolumn{10}{|l|}{ Sai-Yok, cave II } \\
\hline one individual & 4000 to 10000 & $\begin{array}{c}\text { cultural } \\
\text { estimation }\end{array}$ & Jacob, 1969 & $\begin{array}{l}\text { quartzite stone slab, ochre powder, } \\
\text { faunal offerings }\end{array}$ & Hoabinhian/Neolithic & on the back & flexed on the body & \begin{tabular}{|l|} 
extended, \\
knees upward
\end{tabular} & Jacob, 1969 \\
\hline \multicolumn{10}{|l|}{ Moh Khiew (1991) } \\
\hline MKC91 B1 & $25800 \pm 600$ & charcoal & Pookajorn, 2001 & big block on the body & Hoabinhian & on the back & extended & - & Pookajorn, 2001 \\
\hline MKC91 B2 & $\begin{array}{c}\text { younger than } \\
8420\end{array}$ & stratigraphy & Pookajorn, 2001 & stones on the skull & Hoabinhian & on the left side & right arm flexed & right leg flexed & Pookajorn, 2001 \\
\hline MKC91 B3 & $\begin{array}{c}8420 \text { to } \\
10530\end{array}$ & stratigraphy & Auetrakulvit et al., 2012 & none & Hoabinhian & on the back & $\begin{array}{c}\text { right extended, left } \\
\text { fully flexed }\end{array}$ & extended & Auetrakulvit et al., 2012 \\
\hline MKC91 B4 & $\begin{array}{c}8420 \text { to } \\
10530\end{array}$ & stratigraphy & Auetrakulvit et al., 2012 & none & Hoabinhian & on the back & left extended & - & Auetrakulvit et al., 2012 \\
\hline \multicolumn{10}{|l|}{ Moh Khiew (2008) } \\
\hline burial 1 & $\begin{array}{l}\text { younger than } \\
10650 \pm 420\end{array}$ & stratigraphy & Zeitoun et al., 2013 & none & Hoabinhian & on the back & left arm extended & - & Auetrakulvit et al., 2012 \\
\hline burial 3 & $\begin{array}{l}\text { younger than } \\
10650 \pm 420\end{array}$ & stratigraphy & Zeitoun et al., 2013 & none & Hoabinhian & on the back & right arm flexed & - & Auetrakulvit et al., 2012 \\
\hline burial 4 & $\begin{array}{l}\text { younger than } \\
10650 \pm 420\end{array}$ & stratigraphy & Zeitoun et al., 2013 & none & Hoabinhian & on the left side & $\cdot$ & flexed & Auetrakulvit et al., 2012 \\
\hline burial 6 & $\begin{array}{l}\text { younger than } \\
11220 \pm 510\end{array}$ & stratigraphy & Zeitoun et al., 2013 & none & Hoabinhian & on the back & extended & - & Auetrakulvit et al 2012 \\
\hline Pha Phen & $6910 \pm 40$ & direct & Tayles et al.. 2015 & none & & on the right side & flexed & fully flexed & Tayles et al., 2015 \\
\hline \multicolumn{10}{|l|}{ Du Sang } \\
\hline & $\begin{array}{c}\text { Hoabihian } \\
\text { culural } \\
\text { estimation }\end{array}$ & stratigraphy & Viet, 2015 & under blocks & Hoabinhian & on the back & extended & flexed & Viet, 2015 \\
\hline \multicolumn{10}{|l|}{ Xom Trai } \\
\hline Hang Cho & $9259 \pm 206$ & direct & Matsumura et al., 2008 & none & Hoabinhian & on the back & flexed & Hexeu, laıseu & Matsumura et al., 2008 \\
\hline $\begin{array}{l}\text { Con Moong cave } \\
\text { burial intruding Layer I }\end{array}$ & $\begin{array}{c}\text { between } 9905 \\
\pm 150 \text { and } \\
11840 \pm 75 \\
\end{array}$ & stratigraphy & Thong, 1980 \& Ha, 1980 & ochre powder, shells & Hoabinhian & on the back & - & flexed & $\mathrm{Ha}, 1980$ \\
\hline \begin{tabular}{|l} 
Mai Da Nuoc \\
84/MDN.M1
\end{tabular} & $\begin{array}{c}\text { Son Vi culural } \\
\text { estimation }\end{array}$ & stratigraphy & Cuong, 1986 & $\begin{array}{c}\text { lithic artefacts, half-ground } \\
\text { seashells, large stones at the basis }\end{array}$ & Hoabinhian & on the back & extended & extended & Cuong, 1986 \\
\hline $\begin{array}{l}\text { Con Co Ngua } \\
5 \text { among } 94 \text { individuals }\end{array}$ & 6000 to 6500 & $\begin{array}{c}\text { Da But culural } \\
\text { estimation }\end{array}$ & Oxenham, 2006 & limited grve offerings & Son Vi / Hoabinhian & on the back & flexed & fflexed & Tayles et al., 2015 \\
\hline $\begin{array}{l}\text { Gua Gunung Runtuh } \\
\text { burial } 1\end{array}$ & $\begin{array}{l}9460 \pm 90 \text { to } \\
10120 \pm 110\end{array}$ & shell & Zuraina, 1994 & $\begin{array}{c}\text { slab sprinkled with red powder, a } \\
\text { quartz hammer stone, oval unifacial } \\
\text { pebble tool }\end{array}$ & Hoabinhian & on the back & flexed & flexed & Jacob and Soepriyo, 1994 \\
\hline \begin{tabular}{|l} 
Gua Teluk Kalawar \\
burial 1
\end{tabular} & $8400 \pm 40$ & shell & Zuraina et al., 2005 & Hoabinhian tool, haematite powder & Hoabinhian & on the back & $\begin{array}{c}\begin{array}{c}\text { right fully flexed, } \\
\text { left flexed }\end{array} \\
\end{array}$ & $\cdot$ & Zuraina et al., 2005 \\
\hline
\end{tabular}

\section{Table 1}

Comparative samples of Hoabinhian burials.

Due to the lack of an accurate count in the different sites, the "crouched" burials from the Zengpiyan cave (northern part of Guangxi province) from period IV (12,000 - $8000 \mathrm{BP})$ and from Liyuzui (central Guangxi province) for period I (9000-8000 BP) described by (Rispoli 2007) are not included in the table.

\section{Table 2}

Anatomical measurements of the different graves (measurements in $\mathrm{mm})$.

\begin{tabular}{|l|c|c|c|c|c|c|c|c|c|}
\hline Individual & SPU & DCOX & IIMT & ISMM & SCOX & SS & SA & SIS & VEAC \\
\hline dpk DE-5 & & 221 & & & 146 & 73 & & 36.5 & \\
\hline dpk D-4 & 37 & 210 & 27 & & 141 & 53 & 73 & 41.5 & 56 \\
\hline dpk E5 & & 207 & 27.2 & 102 & 124 & 62.8 & 61 & 32 & 54 \\
\hline
\end{tabular}

SPU: Cotylo-pubic width, DCOX: Innominate or coxal length, IIMT: Greater sciatic notch height, ISMM: Ischium post-acetabular length, SCOX: Iliac or coxal breath, SS: Spino-sciatic length, SA: Spino-auricular length, SIS: Cotylo-sciatic breadth, VEAC: Vertical acetabular diameter. According to Murail et al. 2005. 


\begin{tabular}{|c|c|c|c|c|c|c|c|c|}
\hline \multicolumn{2}{|c|}{ Taxa } & & & Number of Remains & $\%$ & \multirow{2}{*}{$\begin{array}{c}\text { Weight of Remains (g) } \\
4408\end{array}$} & \multirow{2}{*}{$\begin{array}{c}\% \\
42,2 \\
\end{array}$} & \multirow{2}{*}{$\frac{\text { average weight }}{11,2}$} \\
\hline \multirow[t]{13}{*}{ Artiodactyla } & bovidae & \multirow{3}{*}{$\begin{array}{l}\text { Bos } \\
\text { Bos } \\
\text { Bos }\end{array}$} & \multirow{3}{*}{$\begin{array}{c}\text { sp } \\
\text { gaurus } \\
\text { javanicus }\end{array}$} & \multirow{3}{*}{$\begin{array}{c}395 \\
5 \\
2\end{array}$} & $\begin{array}{r}\% \\
9,3 \\
\end{array}$ & & & \\
\hline & & & & & 0,1 & 128 & 1,2 & 25,6 \\
\hline & & & & & 0,0 & 20 & 0,2 & 10,0 \\
\hline & & Capricornis & sp & 2 & 0,0 & 10 & 0,1 & 5,0 \\
\hline & cervidae & large size & & 534 & 12,5 & 2084 & 20,0 & 3,9 \\
\hline & & middle size & & 22 & 0,5 & 54 & 0,5 & 2,5 \\
\hline & & small size & & 3 & 0,1 & 5 & 0,0 & 1,7 \\
\hline & & Cervus & unicolor & 17 & 0,4 & 297 & 2,8 & 17,5 \\
\hline & & Cervus & eldii & 1 & 0,0 & 4 & 0,0 & 4,0 \\
\hline & & Muntiacus & muntjak & 2 & 0,0 & 4 & 0,0 & 2,0 \\
\hline & & Muntiacus & sp & 60 & 1,4 & 100 & 1,0 & 1,7 \\
\hline & bovidae/cervidae & & & 44 & 1,0 & 241 & 2,3 & 5,5 \\
\hline & suidae & Sus & sp & 39 & 0,9 & 230 & 2,2 & 5,9 \\
\hline Perissodactyla & rhinocerotidae & & & 3 & 0,1 & 178 & 1,7 & 59,3 \\
\hline \multirow[t]{5}{*}{ Primates } & & & & 16 & 0,4 & 31 & 0,3 & 1,9 \\
\hline & cercopithecidae & Trachypithecus & & 7 & 0,2 & 21 & 0,2 & 3,0 \\
\hline & & Macaca & $s p$ & 1 & 0,0 & 3 & 0,0 & 3,0 \\
\hline & & Nycticebus & $s p$ & 1 & 0,0 & 2 & 0,0 & 2,0 \\
\hline & hylobatidae & Hylobates & sp & 1 & 0,0 & 1 & 0,0 & 1,0 \\
\hline \multirow[t]{6}{*}{ Carnivora } & & & & 10 & 0,2 & 10 & 0,1 & 1,0 \\
\hline & \begin{tabular}{|l} 
mustelidae \\
\end{tabular} & Arctonyx & collaris & 3 & 0,1 & 9 & 0,1 & 3,0 \\
\hline & \begin{tabular}{|l|} 
viverridae \\
\end{tabular} & & & 8 & 0,2 & 16 & 0,2 & 2,0 \\
\hline & felidae & Prionailurus & bengalensis & 3 & 0,1 & 3 & 0,0 & 1,0 \\
\hline & & Panthera & pardus & 2 & 0,0 & 3 & 0,0 & 1,5 \\
\hline & ursidae & Helarctos & malayanus & 2 & 0,0 & 20 & 0,2 & 10,0 \\
\hline Lagomorpha & Teporidae & Lepus & peguensis & 1 & 0,0 & 1 & 0,0 & 1,0 \\
\hline \multirow[t]{5}{*}{ Rodentia } & & & & 91 & 2,1 & 43 & 0,4 & 0,5 \\
\hline & hystricidae & Hystrix & sp & 10 & 0,2 & 7 & 0,1 & 0,7 \\
\hline & & Atherurus & sp & 10 & 0,2 & 7 & 0,1 & 0,7 \\
\hline & muridae & Cannomys & badius & 3 & 0,1 & 2 & 0,0 & 0,7 \\
\hline & \begin{tabular}{|l} 
sciuridae \\
\end{tabular} & Petaurista & sp & 1 & 0,0 & 2 & 0,0 & 2,0 \\
\hline Chiroptera & & & & 4 & 0,1 & 2 & 0,0 & 0,5 \\
\hline Insectivora & & & & 2 & 0,0 & 1 & 0,0 & 0,5 \\
\hline Columbiformes & columbidae & & & 1 & 0,0 & 1 & 0,0 & 1,0 \\
\hline \multirow[t]{2}{*}{ Testudines } & & & & 937 & 22,0 & 1413 & 13,5 & 1,5 \\
\hline & testudinidae & Indotestudo & elongata & 6 & 0,1 & 17 & 0,2 & 2,8 \\
\hline \multirow[t]{10}{*}{ Squamata } & & & & 8 & 0,2 & 5 & 0,0 & 0,6 \\
\hline & serpentes & & & 12 & 0,3 & 7 & 0,1 & 0,6 \\
\hline & elapidae & Ophiophagus & hannah & 4 & 0,1 & 8 & 0,1 & 2,0 \\
\hline & \begin{tabular}{|l|} 
pythonidae \\
\end{tabular} & Malayopython & reticulatus & 2 & 0,0 & 4 & 0,0 & 2,0 \\
\hline & \begin{tabular}{|l} 
colubridae \\
\end{tabular} & & & 10 & 0,2 & 11 & 0,1 & 1,1 \\
\hline & \begin{tabular}{|l|} 
viperidae \\
\end{tabular} & & & 1 & 0,0 & 0 & 0,0 & 0,0 \\
\hline & lacertidae & & & 2 & 0,0 & 0 & 0,0 & 0,0 \\
\hline & \multirow[t]{3}{*}{ varanidae } & \multirow{3}{*}{$\begin{array}{l}\text { Varanus } \\
\text { Varanus } \\
\text { Varanus }\end{array}$} & sp & 308 & 7,2 & 326 & 3,1 & 1,1 \\
\hline & & & bengalensis & 2 & 0,0 & 2 & 0,0 & 1,0 \\
\hline & & & salvator & 2 & 0,0 & 3 & 0,0 & 1,5 \\
\hline Amphibia & & & & 15 & 0,4 & 7 & $\overline{0,1}$ & 0,5 \\
\hline Siluriformes & bagridae & Mystus & & 1 & 0,0 & 1 & 0,0 & 1,0 \\
\hline Ustelcintnyes & & & & 14 & 0,3 & 10 & 0,1 & 0,7 \\
\hline Brachyura & & & & 850 & 20,0 & 177 & 1,7 & $\overline{0,2}$ \\
\hline Bivalvia & & & & 143 & 3,4 & 110 & 1,1 & 0,8 \\
\hline & unionidae & & & 82 & 1,9 & 133 & 1,3 & 1,6 \\
\hline Pulmonata & stylomatophora & & & 541 & 12,7 & 241 & 2,3 & 0,4 \\
\hline & cyclophoridae & Cyclophorus & sp & 9 & 0,2 & 13 & 0,1 & 1,4 \\
\hline & & & determined & 4255 & 13,4 & 10437 & 33,3 & 2,5 \\
\hline & & & undeterminated & 27443 & 86,6 & 20874 & 66,7 & 0,8 \\
\hline & & & Total & 31698 & 100,0 & 31311 & 100,0 & 1,0 \\
\hline
\end{tabular}

Table 3

Faunal remains discovered at Doi Pha Kan (modified from Frère et al. 2018). 


\begin{tabular}{|c|c|c|c|c|}
\hline Site & Material support & Age $\mathbf{B P} \pm 1 \sigma$ & Age BC (cal) & Lab references \\
\hline dpk DE-5 & Human femoral shaft & $11,895 \pm 45$ & $11,955-11,641$ & SacA 32917 \\
\hline dpkE-5 & $\begin{array}{l}\text { Human third molar } \\
\text { Human femoral shaft } \\
\text { Muntiac-metapod diaphysis } \\
\text { Fresh water oyster shell } \\
\text { Charcoal }\end{array}$ & $\begin{array}{r}11,170 \pm 40 \\
12,540 \pm 50 \\
12,210 \pm 50 \\
12,920 \pm 80 \\
12,930 \pm 50 \\
\end{array}$ & $\begin{array}{c}11,263-10,929 \\
13,169-12,462 \\
12,296-11,895 \\
14,242-13,077 \\
14,156-13,114 \\
\end{array}$ & $\begin{array}{l}\text { Sacd } 27054 \\
\text { Sacd } 27053 \\
\text { Sacd } 27055 \\
\text { Sacd } 27057 \\
\text { Sacd } 27056 \\
\end{array}$ \\
\hline dpk,D-4 & Human femoral shaft & $12,340 \pm 50$ & $12,719-12,081$ & SacA32916 \\
\hline
\end{tabular}

Table 4

Direct dating of the material from the burials at Doi Pha Kan.

\section{References}

Auetrakulvit, P., Forestier, H., Khaokhiew, C., Zeitoun, V., 2012. New Excavation at Moh Khiew Site (Southern Thailand). In: Bonatz, D., Reinecke, A., Tjoa-Bonatz, M-L. (Eds.), Crossing Borders in Southeast Asian Archaeology. NUS Press, Singapore, pp. 62-74.

Bellwood, P., 1993. Cultural and biological differentiation in Peninsular Malaysia: the last 10,000 years. Asian Perspectives 32, 37-60.

Bellwood, P. 2018. The search for ancient DNA heads east. Science 361, 31-32.

Bulbeck, D., 2000. Dental morphology at Gua cha, West Malaysia, and the implications for "sunadonty". Indo-Pacific Prehistory Association Bulletin 19, 17-41.

Bulbeck, D., n.d. The Gua Cha burials - concordance, chronology, demography. Unpublished report.www.keene.edu/library/OrangAsli/guachay.pdf.https://www.researchgate.net/publication/2 37324132.

Callenfels, V. S., 1939. Report on an excavation in the rock-shelter gol Ba'it, near sungai Siput (Perak). Proceeding of the third congress of Prehistorians of the Far-East, Singapore. 119-30.

Celiberti, V., Forestier, H., Auetrakulvit, P., Zeitoun, V., 2018. Doi Pha Kan, Lampang province, north of Thailand: a new lithic assemblage in the Hoabinhian chrono-cultural context. In : Tan, N. (Ed.), Advancing Southeast Asian Archaeology, SEAMEO SPAFA Regional Centre for Archaeology and Fine Arts, Bangkok, pp. 91-99, 316-319.

Colani, M., 1930. Recherches sur le Préhistorique indochinois. Bulletin de l'Ecole française d'Extrême-Orient 30, 299-422.

Colani, M., 1927a. Découverte de la grotte sépulcrale de Lang Gao (province de Hoa-Binh, Tonkin). L’Anthropologie, 37: 227-29.

Colani, M., 1927b. L’Age de la Pierre dans la Province de Hoa-Binh (Tonkin). Mémoires du Service Géologique de 1'Indochine, 14, 1-86.

Cuong, N. L., 1986. Two early Hoabinhian crania from Thanh Hoa province, Vietnam. Zeitschrift für Morphologie und Anhropologie 77, 11-17.

Duday, H., Courtaud, P., Crubézy, E., Sellier, P., Tillier, A-M., 1990. L'anthropologie de terrain 
reconnaissance et interprétation des gestes funéraires. Bulletins et Mémoires de la Société d'Anthropologie de Paris 2, pp. 29-50.

Duday, H., Guillon, M., 2006. Understanding the circumstances of decomposition when the body is skeletonised. In: Schmitt, A., Cunha, E., Pinheiro, J. (Eds.), Forensic Anthropology and Medicine Complementary Sciences from Recovery to Cause of Death. Human Press, Totowa, New Jersey, pp. 117-57.

Forestier, H., Sophady, H., Puaud, S., Celiberti, V., Frère, S., Zeitoun, V., Mourer-Chauviré, C., Mourer, R., Than, H., Billault, L., 2015. The Hoabinhian of laang Spean cave in his stratigraphical and chronological context, (Cambodia, Battambang Province). Journal of Archaeological Science: Reports, 194-206.

Frère, S., Auetrakulvit, P., Zeitoun, V., Sophady, H., Forestier, H., 2018. Doi Pha Kan, Bantha Si (Thailand) and Laang Spean (Cambodia) Late Paleolithic animal bone assemblages: a new perception of meat supply strategies for early Holocene mainland Southeast Asia. In : Tan, N. (Ed.), Advancing Southeast Asian Archaeology, SEAMEO SPAFA Regional Centre for Archaeology and Fine Arts, Bangkok, pp. 100-108, 320-323.

Ha, V.T., 1980. Nouvelles recherches préhistoriques et protohistoriques au Vietnam. Bulletin de l'Ecole Française d'Extrême-Orient 68, 113-54.

Ha, V.T., 1995. Différentes lignes de développement du post-Hoabinhien à l'Âge de la Pierre au Vietnam. L'Anthropologie 99, 652-656.

Harris, N. , Tayles, N., 2012. Burial containers- A hidden aspect of mortuary practices: Archchaeothanatology at Ban Non Wat, Thailand. Journal of Anthropological Archaeology 31, 227-239.

Hiep, T., H., Huffer, D. 2015. The Da But period in northern Vietnam: Current knowledge and future directions. Journal of Indo-Pacific Archaeology 35, 36-47.

Higham, C., 2002. Early cultures of Mainland outheast Asia. River Books.

Higham, C., 2013. Hunter-gatherers in Southeast Asia: from prehistory to the present. Human Biology 85, 21-43.

Higham, C., Higham, T., 2009. A new chronological framework for prehistoric Southeast Asia, based on a Bayesian model from Ban Non Wat. Antiquity 83, 125-44.

Higham, C., O’Reilly, D., 2004. Social aspects of the Ban Lum Khao cemetery. In: Higham, C., Thosarat, R. (Eds.), The Origins of the Civilization of Angkor: the Excavation of Ban Lum Khao. The Fine Arts Department, Bangkok, pp. 301-23.

Imdirakphol, S., Zazzo, A., Auetrakulvit, P., Tiamtinkrit, C., Pierret, A., Forestier, H., Zeitoun, V., 2017. The perforated stones of the Doi Pha Kan burials (Northern Thailand): a Mesolithic singularity? Palevol 16, 351-61. 
Jacob, T., 1967. Some problem pertaining the racial history of the Indonesian region. $\mathrm{PhD}$ dissertation, University of Utrecht. Drukkeri Neerlandia.

Jacob, T., 1969. The Mesolithic skeletal remains from Sai-Yok. In : Sangvichien S., Sirigaroon P., and Jørgensen J.B. (Eds.). Archaeological Excavations in Thailand, Vol. III: Ban-Kao. Part Two: The Prehistoric Thai Skeletons, Munksgaard, Copenhagen, pp. 49-52.

Jacob, T., Soepriyo, A., 1994. A preliminary palaeoanthropological study of the Gua Gunung Runtuh hman skeleton. In : Zuraina, M. (Ed.), The excavation of Gua gunng Runtuh and the discovery of the Perak man in Malaysia, Department of Museums and Antiquities, Malaysia, Kuala Lumpur, pp. 48-69.

Ji, X., Kuman, K., Clarke, R., Forestier, H., Li, Y., Ma, J., Qiu, K., Li, H., Wu, Y. 2016. The oldest Hoabinhian technocomplex in Asia (43.5 ka) at Xiaodong rockshelter, Yunnan province, southwest China. Quaternary International 400, 166-174.

Lloyd-Smith, L., 2012.Early Holocene burial practice at Niah cave, Sarawak. Journal of IndoPacific Archaeology 32, 54-69.

Mahakkanukrauh, P., Khanpetch, P., Prasitwattanseree, S., Vichairat, K., Case, D., 2011. Stature estimation from long bone lengths in a thai population. Forensic Science International 210, 279.e1279.e7

Mansuy, H., 1909. Gisement préhistorique de la caverne de Pho-binh-gia (Tonkin). L'Anthropologie 20, 531-43.

Mansuy, H., 1924. Contribution à l'étude de la préhistoire de l'indochine. IV Stations préhistoriques dans les caverns du massif calcaire de Bac-son (Tonkin). Mémoires du Service Géologique de l'Indochine 9, 1-37.

Mansuy, H., 1925a. Contribution à l'étude de la préhistoire de l'Indochine V. Nouvelle découvertes dans les cavernes du massif calcaire de Bac-Son (Tonkin). Mémoires du Service Géologique de l'Indochine 12, 1-39.

Mansuy, H., 1925b. Contribution à l'étude de la préhistoire de l'Indochine VI. Stations préhistoriques de Khac-Kiêm (suite), de Lai-Ta et de Bang-Mac, dans le massif calcaire de BacSon (Tonkin). Note sur deux instruments en pierre polie provenant de l'île de Trê (Annam). Mémoires du Service Géologique de l’Indochine 12, 1-21.

Mansuy, H., 1925c. Contribution à l'étude de la préhistoire de l'Indochine VIII. La caverne sépulcrale Néolithique de Hamrong, prés Thanh-Hoa (Annam). Bulletin du Service Géologique de l'Indochine, 14, 1-12.

Mansuy, H., Colani, M., 1925. Contribution a l'étude de la préhistoire de l'Indochine VII. Néolithique inférieur (Bacsonien) et Néolithique supérieur dans le Haut-Tonkin (derniéres recherches). Mémoires du Service Géologique de l'Indochine 12, 1- 46. 
Marean, C.-W., Cleghorn, N., 2003. Large Mammal skeletal element transport applying foraging theory in a complex. Journal of Taphonomy 1, 15-42.

Matsumura, H., Oxenham, M., 2014. Transition and migration in prehistoric East/southeast Asia throug the lens of nonmetric dental traits. American journal of Physical anthropology 155, 45-65.

Matsumura, H., Oxenham, M., Cuong., N., L., 2015. Hoabinhians: A Key Population with which to debate the peopling of Southeast Asia in Kaifu, Y., Izuho M., Goebel T. Sato H., Ono A. Emergence and diversity of human behavior Paleolithic Asia. Texas A\&M University Press. pp. 117-132.

Matsumura, H., Yoneda, M., Dodo, Y., Oxenham, M., Cuong, N. L., Thuy, N. K., Dung, L. M., Long, V. T., Yamagata, M., Sawada, J., Shinoda, K., Takigawa, W., 2008. Terminal Pleistocene human skeleton from Hang Cho cave, northen Vietnam: implications for the biological affinities of hoabinhian people. Anthropological Science 116, 201-17.

Murail, P., Brùzek, J., Houët, F., Cunha, E., 2005. DSP: a tool for probabilistic sex diagnosis using worldwide variability in hip-bone measurements. Bulletins et Mémoires de la Société Anthropologique de Paris 17, 167- 76.

Orlando, L., Gilbert, M., Willerslev, E. 2015. Applications of next generation sequencing reconstructing ancient genomes and epigenomes. Nature Reviews Genetics 16, 395-408.

Oxenham, M., 2000. Health and behavior during the Mid-holocene and Metal period of Northern Vietnam. PhD thesis Northern territory University, Darwin, NT Australia.

Oxenham, M., 2006. Biological responses to change in prehistoric Vietnam. Asian Perspectives 45, 212-39.

Oxenam, M., Thuy, N., K., Cuong, N., L., 2005. Skeletal evidence for emergence of infectious disease in Bronze and Iron age Northern Vietnam. American Journal of Physical Anthropology $126,359-376$.

Patte, E., 1932. Le kjokenmodding de Dabùt et ses sepultures (province de Tanh Hoa, Indochine). Bulletin du Service Géologique de l'Indochine 19, 1-68.

Pautreau J.P., Mornais P., Doy Asa, T., 2001. Ban Wang Hai, un cimetière de l'âge du Fer en Thaïlande du Nord. Silkworms book.

Pautreau, J.-P., Mornais, P., Doy Asa, T., 1998. Le cimetière protohistorique de Ban Wang Hi. Archéologia 351, 46-54.

Pookajorn, S., 1990. Hoabinhian cave excavations in Ban Kao district, West Thailand. In : Glover, I. and Glover, E. (Eds.), Southeast Asian Archaeology Proceedings of the first conference of the association of southeast Asian Archeologist in western Europe, BAR series 561, pp.11-27.

Pookajorn, S., 1994. Final report of excavations at Moh Khiew cave, Krabi province, Sakai cave, 
Trang province and ethnoarchaeological research of hunter-gatherer group so-called "Sakai or Semang" at Trang province. Bangkok: Department of Archaeology, Silpakorn University Press, Bangkok.

Pookajorn, S., 2001. New perspectives for Palaeolithic research in Thailand. In: Sémah, F., Falgueres, C., Grimaud-Hervé, D. and Sémah, A.-M. (Eds.), Origine des peuplements et chronologie des cultures paléolithiques dans le Sud-est asiatique, Semenanjung, Paris, pp.167-87.

Pureepatpong, N. Sangiampongsa, A., Lerdpipatworakul, T., Sangvichien, S., 2102. Stature estimation of modern Thais from long bones: a cadaveric study. Siriraj Medical Journal 64, 22-25.

Pureepatpong, N., 2006. Recent investigation of early peoplemapha district, (Late Pleistocene to Early Holocene) from Ban Rai and Tham Lod rock shelter sites, Pang Mapha district, Mae Hong Son province, Norhwestern Thailand. In : Bacus, E., Glover, I, Pigott, V. (Eds.), Uncovering Southeast Asia's past, NUS Press, Singapore, pp. 38-45.

Rispoli, F. 2007. The incised and impressed pottery style of mainland Southeast Asia following the paths of neolithization. East and West 57, 235-304.

Shoocongdej, R., 2006. Late Pleistocene activities at the Tham Lod rockshelter in Highland Pang Mapha, Mae Hong Son province, Norhwestern Thailand. In : Bacus, E., Glover, I, Pigott, V. (Eds.), Uncovering Southeast Asia's past, NUS Press, Singapore, pp. 22-37.

Sidisunthorn, P., Gardner, S., Smart, D., 2006. Caves of Northern Thailand. River Books, Bangkok.

Surinlert, J., Auetrakulvit, P., Zeitoun, V., Tiamtinkrit, C., Khemnak, P., 2018. Prehistoric rock-art at Doi Pha Kan, Lampang province, Thailand. In : Tan, N. (Ed.), Advancing Southeast Asian Archaeology, SEAMEO SPAFA Regional Centre for Archaeology and Fine Arts, Bangkok, pp. 248-254, 380-382.

Tayles, N., Halcrow, S., Sayavongkhamdy, T., Sousavatdy, V., 2015. A prehistoric flexed human burial from Pha Phen, Middle Mekong Valley, Laos: its context in southeast Asia. Anthropological Science 123, 1-12.

Thong, P. T., 1980. Con Moong cave. A noteworthy archaeological discovery in Vietnam. Asian Perspectives 23, 17-21.

Van Heekeren, H.R., 1961. A preliminary note on the excavation of the Sai-Yok rock-shelter. Journal of the Siam Society 49, 99-108.

Viet, N., 2015. First Archaeological Evidence of Symbolic Activities from the Pleistocene of Vietnamin in Kaifu, Y., Izuho M., Goebel T. Sato H., Ono A. Emergence and diversity of human behavior Paleolithic Asia. Texas A\&M University Press. pp. 133-139.

Viet, N., 2005. The Da but culture: Evidence for cultural development in Vietnam during the Middle Holocene. Bulletin of the Indo-Pacific Prehistory Association 25, 89-93. 
White, J., 2011. Cultural Diversity in Mainland Southeast Asia: A View from Prehistory. In : Enfield, N. J. (Ed.), Dynamics of Human Diversity: The Case of Mainland Southeast Asia, Pacific Linguistics, Canberra, pp. 9-46.

White, J., n.d. Changing Paradigms in Southeast Asian Archaeology. Keynote Address for the $14^{\text {th }}$ International Conference of the European Association for Southeast Asian Archaeologists, 18-21 September 2012, Dublin, Ireland. Accepted for publication in conference proceedings.

Willis, A., Tayles, N., 2009. Field anthropology: application to burial contexts in prehistoric Southeast Asia. Journal of Archaeological Science 36, 547-54.

Zazzo, A., 2014. Bone and enamel carbonate diagenesis: A radiocarbon prospective. Palaeogeography, Palaeoclimatology, Palaeoecology 416, 168-78.

Zazzo, A., Saliège, J.-F., 2011. Radiocarbon dating of biological apatites: A review. Palaeogeography, Palaeoclimatology, Palaeoecology 310, 52-61.

Zeitoun, V., Auetrakulvit, P., Forestier, H., Zazzo, A., Davtian, G., Nakbunlung, S., Tiamtinkrit, C., 2013. Discovery of a Mesolithic burial near the painted rock-shelter of Ban Tha Si (Lampang province, Northern Thailand): implications for regional mortuary practices. Palevol 12, 127-36.

Zeitoun, V., Forestier, H., Sophady, H., Puaud, S., Billault, L., 2012. Direct Dating of a Neolithic Burial in the Laang Spean cave (Battambang Province, Cambodia): first regional chrono-cultural implications. Palevol 11, 529-37.

Zuraina, M. 1994. The excavation of Perak man, an epi-Palaeolithic burial at Gua Gunung Runtuh. In : Zuraina, M. (Ed.), The excavation of Gua gunng Runtuh and the discovery of the Perak man in Malaysia. Department of Museums and Antiquities, Malaysia, Kuala Lumpur, pp. 230-247.

Zuraina, M., Arif, J., Samsuddin, A.R., Nizam, A., Lim, A., Saidin, M., Abdujjah, J., Chia, S., 2005. GTK 1: a skeleton from Gua Teluk Kelawar, Lenggong dated 8,400 \pm 40 BP. In : Zuraina, M. (Ed.), The Perak man and other prehistoric skeletons of Malaysia. Penerbit Universiti Sains Malaysia, Pulau Pinang, pp. 345-61. 